\title{
Mid-Neogene Mediterranean marine-continental correlations: an alternative interpretation
}

\author{
Jean-Pierre Aguilar ${ }^{\mathrm{a}}$, William A. Berggren ${ }^{\mathrm{b}, \mathrm{c}}$, Marie-Pierre Aubry ${ }^{\mathrm{c}}$, \\ Dennis V. Kent ${ }^{\mathrm{c}, \mathrm{d}}$, Georges Clauzon ${ }^{\mathrm{e}}$, Mouloud Benammi ${ }^{\mathrm{f}}$, \\ Jacques Michaux ${ }^{\mathrm{g}, *}$ \\ a Institut des Sciences de l'Evolution (UMR 5554 CNRS), Université Montpellier 2, CC 064, F-34095 Montpellier Cedex 5, France \\ b Department of Geology and Geophysics, Woods Hole Oceanographic Institution, Woods Hole, MA 02543, USA \\ c Department of Geological Sciences, Rutgers University, Piscataway, NJ 08854, USA \\ d Lamont-Doherty Earth Observatory, Palisades, NY 10964, USA \\ e C.E.R.E.G.E. (UMR 6635 CNRS), Europôle de l'Arbois, P.O.Box 80, F-13545 Aix-en-Provence Cedex 04, France \\ f Laboratorio de Paleomagnetismo, Instituto de Geofisica, Universidad Nacional Autonoma de Mexico, 04510 Mexico DF, Mexico \\ g Institut des Sciences de l'Evolution et Laboratoire de Paléontologie de l'EPHE (UMR 5554 CNRS), Université Montpellier 2, \\ CC 064, F-34095 Montpellier Cedex 5, France
}

Received 29 November 2002; received in revised form 6 October 2003; accepted 13 November 2003

\begin{abstract}
Recent revised magnetostratigraphic and astrochronologic calibrations of several calcareous planktonic microfossil datum events (in particular Coccolithus miopelagicus and Neogloboquadrina acostaensis) combined with our magnetobiostratigraphic investigation of a $10 \mathrm{~m}$-thick section at Ecotet, near Lyon (France), in which terrestrial micromammals (Vallesian Zone MN9) are intercalated with calcareous nannoplankton and planktonic foraminifera belonging to Zones NN6-NN8 and N14-15 (= M11 and M12), respectively, lead us to question the recent recalibration by Krijgsman et al. [(1996) Eart Planet. Sci. Lett. 142, 367-380) of the Aragonian/Vallesian (MN7-8/ MN9) boundary with Chron C5r.1r $(\sim 11.1 \mathrm{Ma})$ and the lower/upper Vallesian (MN9/10) boundary with Chron C4Ar.2n ( 9.6-9.7 Ma). Ecotet, with a uniform reverse polarity, is shown to be assignable uniquely to Chron C5r. Interregional correlation of Ecotet with Mediterranean terrestrial stratigraphies indicates that Progonomys (whose First Occurrence (FO) has been traditionally placed in Mediterranean Mammal Zone MN10) was already present in Mediterranean Zone MN9 at $\sim 11.4 \mathrm{Ma}$ and did not experience a 2 million-year delay in its putative prochoresis from Asia.
\end{abstract}

(C) 2003 Elsevier B.V. All rights reserved.

Keywords: Neogene; Mediterranean; mammals; biostratigraphy; paleomagnetic stratigraphy

\section{Introduction}

* Corresponding author. Tel.: +33-4-67144917; Fax: +33-4-67143610.

E-mail address: michaux@isem.univ-montp2.fr (J. Michaux).
One of the objectives of land vertebrate paleontology is to correlate mammal-bearing localities with the geomagnetic polarity time scale (GPTS). 
Because radioisotopically datable levels are scarce, the dating of a large number of localities has been achieved through correlations with the marine record. For more than a decade magnetostratigraphy has provided the only means of calibration, in particular in exclusively continental basins. Several syntheses have been recently proposed for the European Neogene record, mainly based on studies in Spain (Krijgsman et al., 1996; Garcés et al., 1996; Agustí et al., 1996, 2001). These revisions raise questions regarding the validity of conclusions reached by studies dealing with other parts of the Mediterranean Basin in which direct correlations with marine biostratigraphy were possible. This is particularly true with respect to middle to lower-upper Miocene correlations.

Our investigation of the shallow marine, micromammal-bearing section of Ecotet, near Lyon, France, has led us to reconsider middle-upper and lower-upper Miocene marine-continental correlations and to address the question of the diachronous migration/entry of Progonomys in Europe.

\section{The Progonomys problem}

The Vallesian European Land Mammal Age (ELMA) comprises Zones MN9 and MN10. Its base ( = Aragonian/Vallesian boundary) is (informally) defined by the First Appearance Datum (FAD) of the equid Hippotherium, an event which is also used to characterize the middle/upper Miocene boundary in the continental record. The lower/upper Vallesian boundary (MN9/MN10 boundary) is delineated by some in Europe (see Agustí, 1990) and North Africa on the basis of the common occurrence of the murid Progonomys.

Re-evaluation of radioisotopic dates on Höwenegg (Germany) suggests an age of 10.3 Ma for the First Occurrence (FO) of Hippotherium in Europe (Swisher, 1996; Woodburne et al., 1996). Correlations established in the Torremormojon section (Sen, 1997a) would indicate that the Aragonian/Vallesian boundary falls within Chron C5n (9.7-10.95 Ma; Cande and Kent, 1995).
However, recent magnetostratigraphic investigations on sections in Spain (Teruel, Duero and Vallès-Penédes Basins (Krijgsman et al., 1996; Garcés et al., 1996; Agustí et al., 1996, 2001)) suggest that the Aragonian/Vallesian (= MN7-8/ MN9) boundary lies in Chron C5r.1r $(\sim 11.1$ $\mathrm{Ma}$; Cande and Kent, 1995) and that the MN9/ MN10 zonal boundary falls in Chron C4Ar.2n (between 9.6 and $9.7 \mathrm{Ma}$ ).

The recalibration of the Aragonian/Vallesian boundary as recently proposed is in contradiction with previous studies in at least two respects: (1) there is ambiguity on the delineation of Zone $\mathrm{MN10}$, and (2) marine-terrestrial correlations in other well-known sections do not support these recent revised correlations.

Agustí et al. (1996, fig. 5 therein) consider that the earliest European representatives of the genus Progonomys occur at the base of Zone MN10. However, the genus Progonomys is represented at Can Llobateres 1 (cited in Hartenberger and Thaler (1963), subsequently illustrated by Michaux (1971) and ultimately referred to by Agustí and Moyà-Solà (1991) and Sen (1997a)) and Pedregueras 2C (Daams et al., 1988; van Dam, 1997). The two localities are referred to Zone MN9 (de Bruijn et al., 1992; Agustí et al., 1996). The lowest occurrence (LO) of the genus is thus recorded in Europe in Zone MN9 (for further discussion see also (Sen, 1997a,b) and Appendix 3).

The essentially marine section at Kastellios Hill yields four mammal-bearing horizons (in upward stratigraphic progression, $\mathrm{K} 1-\mathrm{K} 3$ and K5). Hippotherium is associated with Progonomys in Level $\mathrm{K} 1$ and $\mathrm{K} 3$ but occurs alone in Level K2 (de Bruijn et al., 1971; de Bruijn and Zachariasse, 1979). Level K4 and K6 have been assigned to lower Zone N16 based on the occurrence of Neogloboquadrina acostaensis. The section has yielded a good magnetostratigraphic record (Sen et al., 1986), and Level K4, of reverse polarity, was assigned to what is now referred to as Chron C5r. Based on the revised Integrated Magnetobiochronologic Scale (IMBS) of Berggren et al. (1995) it was reasonable to estimate the presence of Progonomys and Hippotherium in the Mediterranean area at $\sim 11.6$ and $11.4 \mathrm{Ma}$, respectively. 
At Bou Hanifia (Ouda and Ameur, 1978; Sen, 1990), the mammal-bearing Bou Hanifia 1 horizon is located about $90 \mathrm{~m}$ above a tephra layer with a radioisotopic age of $12.03 \pm 0.25 \mathrm{Ma}$ (Sen, 1990). Horizon 1 has yielded Hippotherium and Progonomys, and a reverse polarity thought to represent Chron 10 in the scale of LaBrecque et al. (1977) (Sen, 1990). It should be recalled that Sen (1990) indicated that 'Chron 9 [...] is equivalent to Chron 11 in the recent terminology of Berggren et al. (1985)' and since Chron 11 is equivalent to Chron C5n, this would make the subjacent reverse polarity interval equivalent to Chron C5r in the scale of Cande and Kent (1995) and Berggren et al. (1995). The minimum age of Horizon 1 is thus 11.4-11.1 Ma. Nevertheless, on the basis of Agusti et al.'s interpretation of the Can Llobateres section, Sen (1997a,b) later correlated the first occurrence of Progonomys with Chron C4r.

Whereas the data and interpretations from the Kastellios Hill and Bou Hanifia sections support each other, they are contradicted by the interpretation of continental Spanish sections (Krijgsman et al., 1996; Garcés et al., 1996; Agustí et al., 1996), in particular with regard to the migratory appearance (or FO) of Progonomys in the Mediterranean Basin. Relying on the calibration N15/ N16 biochronal boundary with Chron C5n of Berggren et al. (1995), Krijgsman et al. (1996) reinterpret as Chron $\mathrm{C} 4 \mathrm{r}$ magnetozones earlier identified as Chron $\mathrm{C} 5 \mathrm{r}$ in interbedded marinecontinental sections (Bou Hanifia, Kastellios Hill). The immediate implication of this reinterpretation is that the migration of Progonomys in the Mediterranean area would have occurred $\sim 2$ myr later than previously thought. Krijgsman et al. (1996) also conclude that the planktonic foraminifera are reworked in Level $\mathrm{K} 4$ of the Kastellios section and warn that the radioisotopicallydated tephra layer in the Bou Hanifia section is stratigraphically too far below the mammal-bearing horizon to support a reliable association between the two. Yet, other recent data indicate that Progonomys occurred in Europe much earlier than 9.6-9.7 Ma.

In the Sinap Tepe Formation of Turkey, two murid species occur at a level assigned to Chron
C5n (Sen, 1996, 1997b; Kappelman et al., 1996) with an estimated age of 10.4-10.3 Ma. In Spain, the Bicorp 1 Locality, which has yielded Progonomys teeth, is located $20 \mathrm{~m}$ below a tephra layer with a radioisotopic age of 9.6 $\pm 0.2 \mathrm{Ma}$ (Anadón et al., 1996). Moreover, Progonomys cf. hispanicus has been identified from the Castelnou 1B locality, which is younger than La Grive $\mathrm{M}$ and $\mathrm{La}$ Grenatière, both referred to the upper part of Zone MN8 although they yield a fauna of middle Miocene character (Aguilar et al., 1991).

In view of such contradictions, some authors have proposed a diachronous dispersion of Progonomys from Pakistan, where it occurred at $\sim 12$ Ma (Flynn et al., 1995), to Europe (Garcés et al., 1996) and even a diachronous dispersion has been hypothesized between Eastern and Western Europe (Sen, 1996)

In the final analysis the problem, simply stated, remains: was Progonomys present already at $\sim 11+\mathrm{Ma}$ in Europe/Mediterranean (as it was in Pakistan) or did it appear there only some 2 myr later as a migrant from the east? The discrepancies between these various interpretations hinge on consideration of the following points:

(1) the earliest occurrence of Hippotherium in Europe (Germany), dated at about 10.3 Ma but estimated at $\sim 11.1 \mathrm{Ma}$ on the basis of magnetostratigraphy (Chron C5r.1r; Spain) (Garcés et al., 1996);

(2) the earliest occurrence of Progonomys (MN10) in Europe, consistently found above that of Hippotherium and below the base of the Turolian ELMA with lower limit best age estimate of $\sim 9.3 \mathrm{Ma}$ (Steininger et al., 1996);

(3) the calibration of the FAD of Neogloboquadrina acostaensis with Chron C5n.

If the reinterpretation of the data from Bou Hanifia and Kastellios reviewed above is consistent and reliable, the polarity patterns in these two sections would be younger than Chron C5n. This would also imply a significant time (? hiatus) between the marine planktonic foraminiferalbearing beds of the lower Bou Hanifia Formation (associated with a radioisotopic age of $12.03 \mathrm{Ma}$ ) and the younger non-marine mammal-bearing beds (90 $\mathrm{m}$ above). We believe that the earlier (original) interpretations of the chronology of 


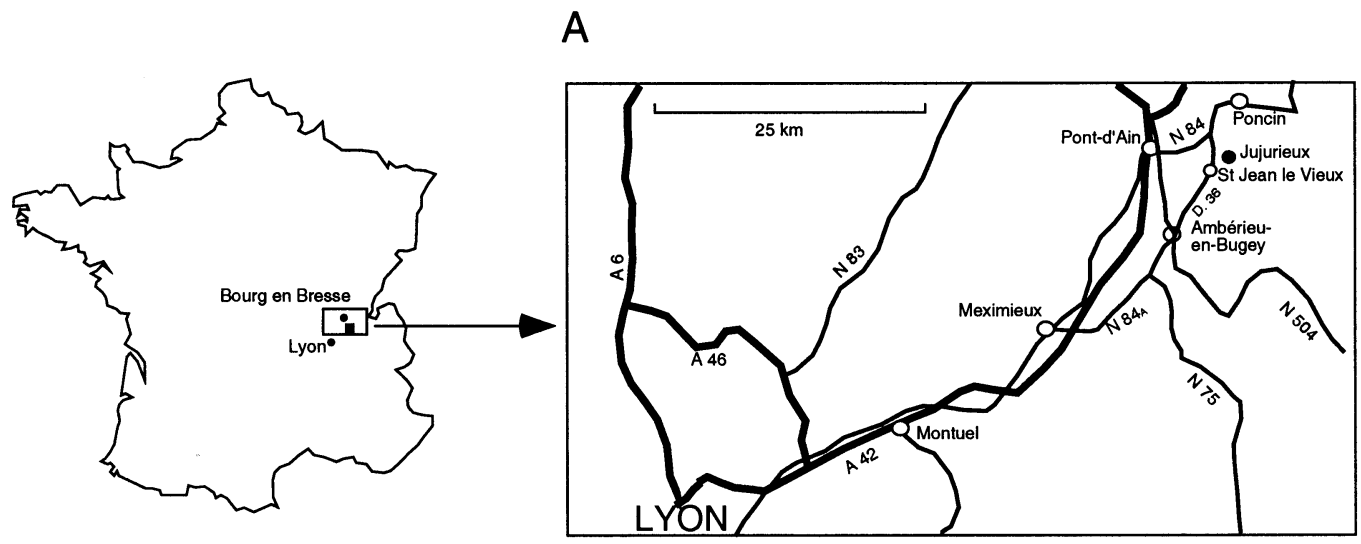

B

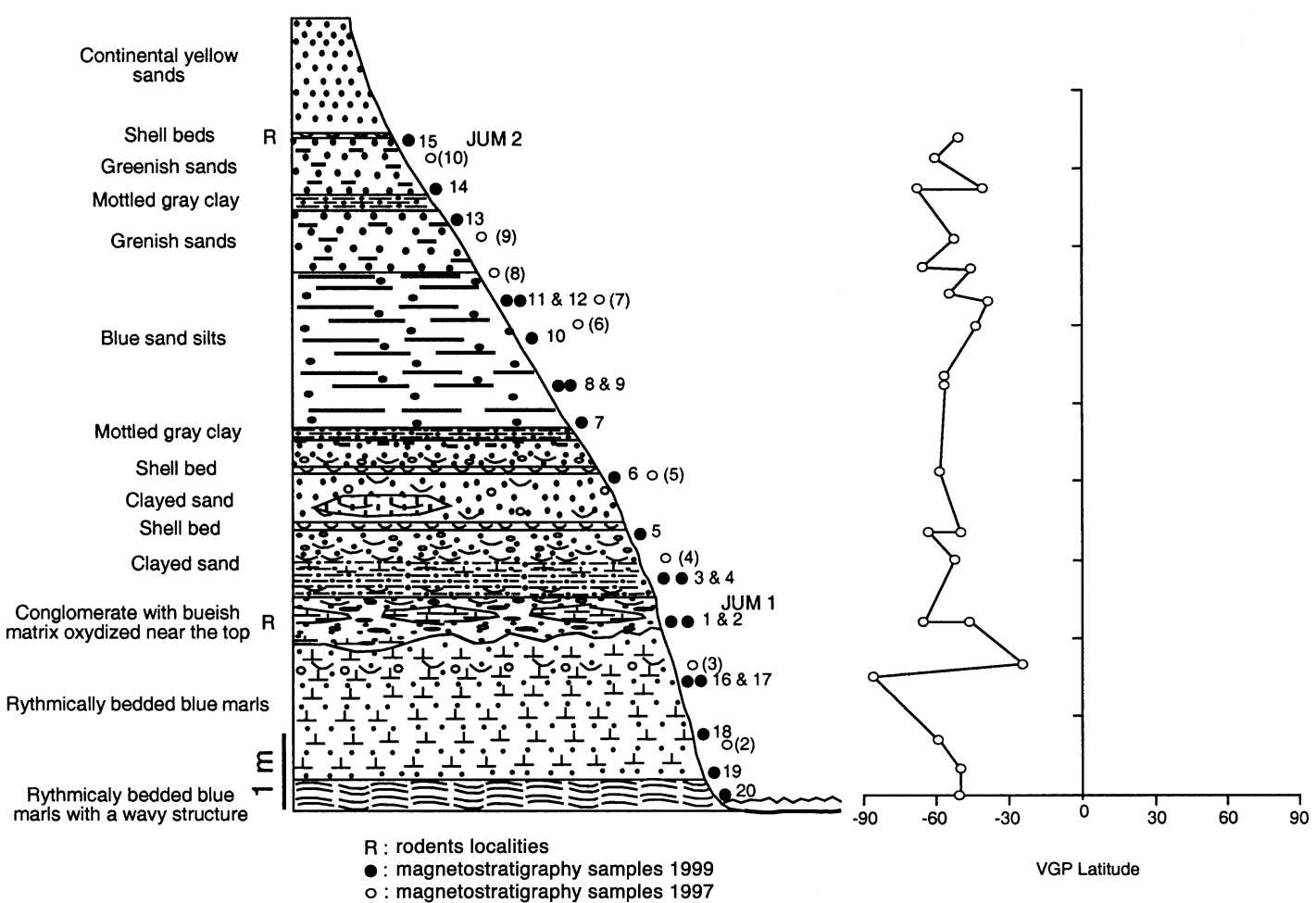

Fig. 1. (A) Location of the section at Ecotet. (B) Lithology and stratigraphic position of sampling levels of Ecotet section. (C) VGP latitudes determined from sample, ChRM directions plotted against stratigraphic level. The entire stratigraphic section is interpreted as reverse polarity. Open circles and number in brackets refer to samples studied at Lamont-Doherty Earth Observatory Laboratory, and solid circles represent samples studied at Laboratorio de Paleomagnetismo at Mexico. 
the Bou Hanifia and Kastellios sections are correct and present our analysis of these sections below, by way of supporting earlier interpretations of the polarity of these two sections as representing Chron C5r. Our study of the Ecotet (Jujurieux) section near Lyon (France) and a review of recent biochronological studies on planktonic foraminifera and calcareous nannoplankton bring pertinent new data to bear on this problem although neither Hippotherium nor Progonomys have been found at Ecotet.

\section{The Ecotet section}

\subsection{The section}

The 10 m-thick Ecotet section (Fig. 1)is located in the Rhone Valley, North of Lyon, on the steep flank of a small river valley near the village of Jujurieux (Fig. 1A,B). It consists of uniformly micaceous siltstones with varying amounts of lignite and quartz sands that would appear to represent deposits of a (near) deltaic source.

The section was first described by Demarcq (1973) who listed its marine paleontologic content. Subsequently, Mein (1985) published a list of mammals which he completed in 1999. In 1991, a group of us (J.P.A., G.C., J.M.) resumed the study of the outcrop at Ecotet, measured a new section (Fig. 1B) located probably near that initially described by Demarcq, and discovered a second level with rodents (JUM 2). Samples for micropaleontologic (M.P.A., W.A.B.) and magnetostratigraphic (D.V.K.) analyses were taken in 1997 and completed with additional samples for magnetostratigraphy (M.B.) in 1999.

\subsection{Magnetostratigraphy}

Oriented (block and drill core) samples were collected from at least 15 different stratigraphic levels in two field campaigns. The initial set of 10 samples was measured and analyzed at the Paleomagnetics Laboratory at Lamont-Doherty Earth Observatory and the subsequent set of 20 samples at the Laboratorio de Paleomagnetismo at the Universidad Nacional Autonoma de Mex- ico (Fig. 1B). Both independently processed sets of samples gave virtually the same results even though different magnetometers (superconducting and spinner, respectively) were used (Figs. 1B,C and 2). Thermal demagnetization data for each specimen, generated at 10 or more temperature steps, were plotted on orthogonal vector diagrams (Zijderveld, 1967) to identify a characteristic component (Fig. 2a), whose direction was then calculated using principal component analysis (Kirschvink, 1980). Out of the 30 samples collected, 25 samples gave acceptable results, all of which indicated reverse polarity with an overall mean direction of Declination $=165.5^{\circ}$ Inclination $=$ $-23.7^{\circ}$ (Fig. 2b). Some fraction of the natural remanent magnetizations (NRM) is typically carried by hematite, as evidenced by high unblocking temperatures. This was also confirmed for bulk properties by isothermal remanent magnetization (IRM) acquisition and thermal demagnetization experiments, which showed a gradual approach to saturation above $300 \mathrm{mT}$ (Fig. 2c), beyond the maximum coercivity expected for magnetite, and maximum unblocking temperatures that range to around $675^{\circ} \mathrm{C}$ (Fig. 2d), typical of hematite. The sediments are gray-colored and show no obvious evidence of weathering; hence the hematite along with magnetite may be detrital components carrying an early acquired and perhaps original record of an ancient geomagnetic field of reverse polarity. This is supported by the shallower than expected magnetization directions, which are most likely due to depositional inclination error.

\subsection{Biostratigraphy}

\subsubsection{Micromammals}

Two horizons interbedded in the shallow marine sediments have yielded micromammals, although with neither Hippotherium nor Progonomys.

The lowest (JUM1), approximately located a quarter of the way up in the section (Fig. 1B), has yielded almost exclusively micromammal teeth (Table 1; faunal list from Mein (1985, 1999), revised and updated).

Significantly, a resampling by Aguilar in 1990 
a)

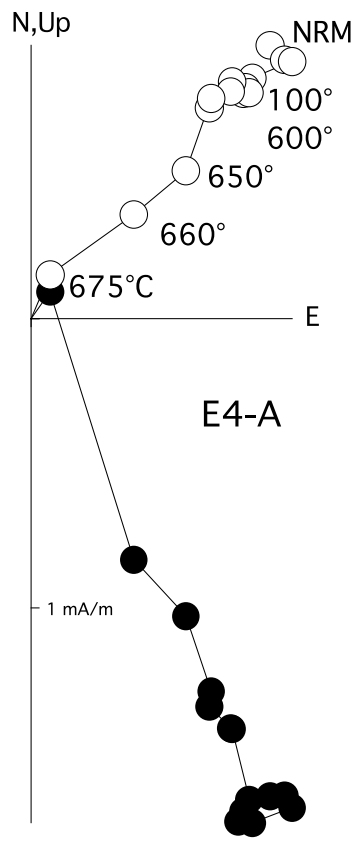

c)

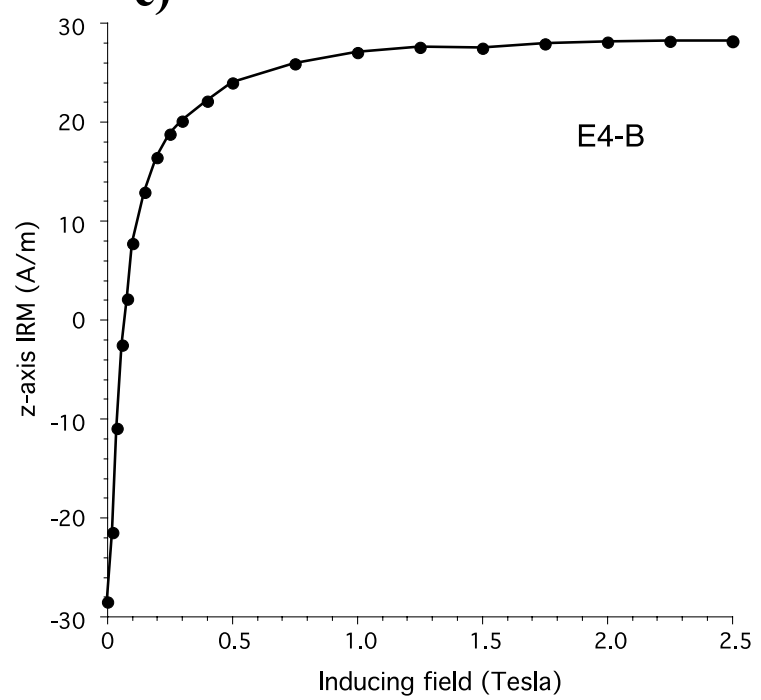

b)

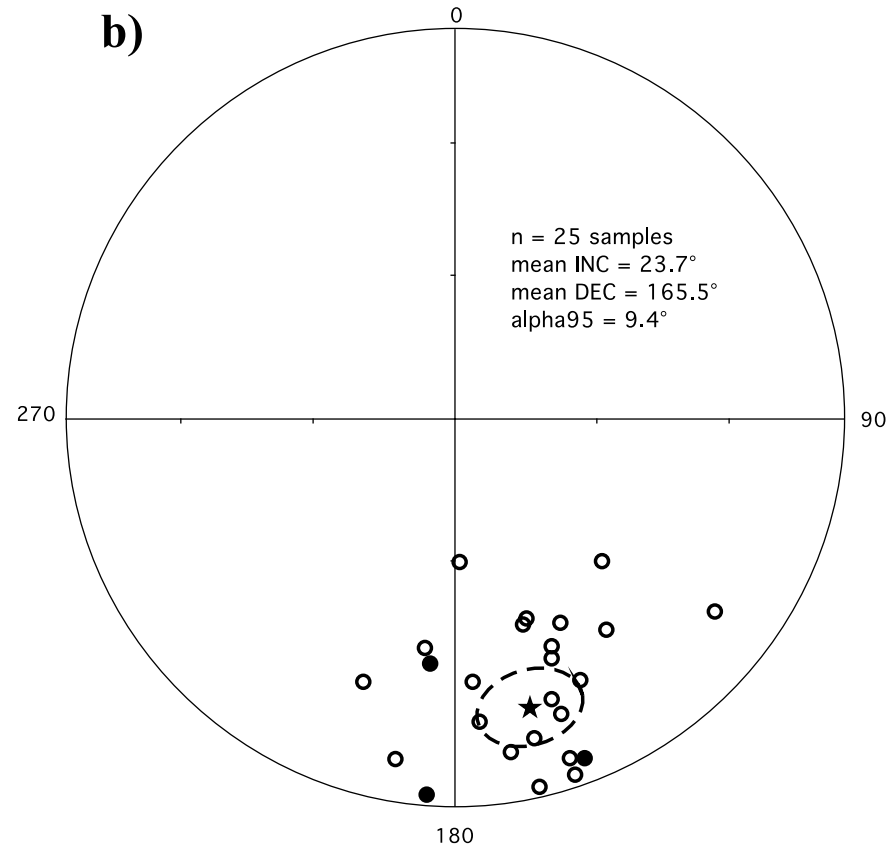

d)

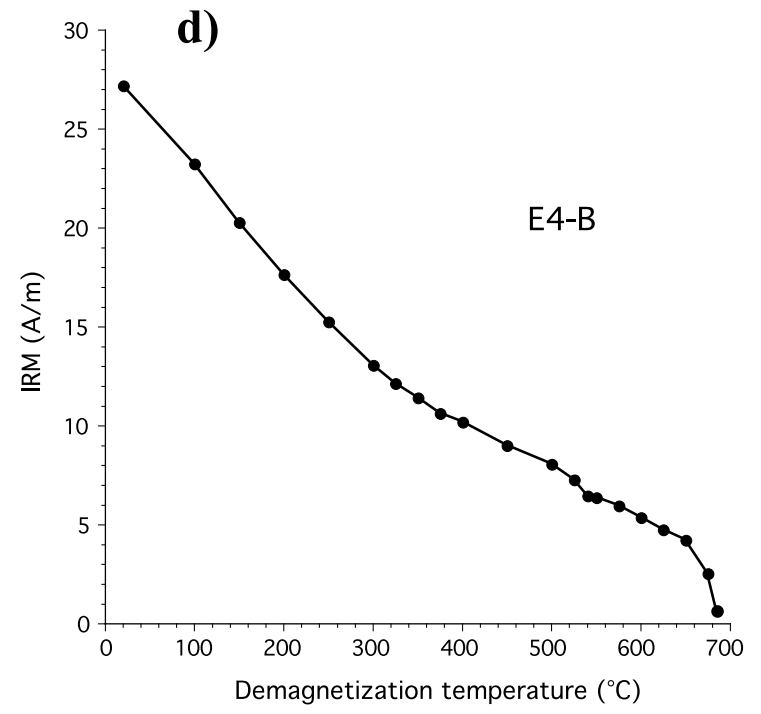

Fig. 2. (a) Examples of typical Zijderveld diagrams for samples studied during thermal cleaning. Demagnetization temperatures are given in ${ }^{\circ} \mathrm{C}$ : Solid (open) circles represent the horizontal (vertical) projection of the NRM vector end-points during demagnetization. (b) Equal-area stereographic projection of characteristic directions after bedding correction. Open circles indicate directions in the upper hemisphere. The $95 \%$ confidence ellipse for the reverse mean directions (shown as star) of the Ecotet section is indicated. (c) Example of IRM as a function of applied impulse field. The strong increase at low fields points to the low coercivity mineral; the saturation above $300 \mathrm{mT}$ beyond the maximum coercivity expected for magnetite indicates the presence of high coercivity mineral. (d) Thermal demagnetization of IRM. The inflexion of the thermal demagnetization curve at about $300^{\circ} \mathrm{C}$ indicates the presence of Ti-rich titanomagnetite, whereas the high maximum unblocking temperature around $675^{\circ} \mathrm{C}$ indicates the presence of hematite in this sample. 
Table 1

Micromammal fauna recovered from JUM 1 and JUM 2 at Ecotet

\begin{tabular}{|c|c|c|}
\hline JUJURIEUX 1 & & \\
\hline Insectivora & Lagomorpha & Carnivora \\
\hline Galerix cf. socialis & Prolagus cf. oeningensis & Trocharion albanensis \\
\hline Galerix sp. & & \\
\hline Urotrichus cf. dolichochir & Rodentia & Artiodactyla \\
\hline Desmanella stehlini & Spermophilinus cf. bredai & Bovidae indet. \\
\hline Talpa cf. minuta & Heteroxerus grivensis & \\
\hline Plesiodimylus chantrei & Trogontherium minutum & \\
\hline Crusafontina endemica & Eomuscardinus cf. sansaniensis & \\
\hline Miosorex ef. grivensis & Muscardinus hispanicus & \\
\hline Paenelimnoecus crouzeli & Glirudinus undosus & \\
\hline Dinosorex pachygnathus & Paraglirulus werenfelsi & \\
\hline & Ramys multicrestatus & \\
\hline Chiroptera & Eomyops catalaunicus & \\
\hline Vespertilionidae indet. & Hispanomys bijugatus & \\
\hline (size of Eptesicus noctiloides) & Megacricetodon debruijni or Megacricetodon minutus & \\
\hline & Democricetodon cf. nemoralis & \\
\hline & Anomalomys cf. gaudryi & \\
\hline & Eumyarion $\mathrm{sp}$ & \\
\hline JUJURIEUX 2 & & \\
\hline Insectivora & Lagomorpha & \\
\hline Galerix sp & Prolagus cf. oeningensis & \\
\hline Dimilidae indet. & & \\
\hline & Rodentia & \\
\hline & Spermophilinus bredai & \\
\hline & Megacricetodon debruijni or Megacricetodon similis & \\
\hline & Myoglis meini & \\
\hline
\end{tabular}

Data from Mein $(1985,1999)$ updated and revised, augmented by our own collections.

of locality JUM1 has yielded Megacricetodon debruijni or M. minutus (one lower M1: $1.30 \times 0.73$ $\mathrm{mm}$ ), with the Insectivora: Miosorex grivensis, Galerix sp., Plesiodimylus chantrei, Talpa minuta (determined by J.-Y. Crochet) and the Lagomorpha Prolagus aff. oeningensis. Mein (1985) regarded such an association as younger than La Grive L3, one of the youngest middle Miocene localities, and proposed that the Ecotet section is correlative with the Saint Fons locality which has yielded Hippotherium primigenium. For Mein $(1985,1999)$ this association which includes Democricetodon cf. nemoralis indicates Zone MN9.

The youngest horizon JUM 2 discovered by Aguilar in 1990, near the top of the marine section, has yielded a poorer micromammal fauna (Table 1) but with Megacricetodon debruijni or M. similis (one lower M1: $1.49 \times 0.93 \mathrm{~mm}$ ). In all Spanish localities, the LO of Megacricetodon debruijni is in Hippotherium-bearing horizons (Carrilanga 1, Pedregueras 2A and 2C (Daams and Freudenthal, 1988); Can Llobateres 1 (Hartenberger, 1965), Can Ponsic 1 (Hartenberger and Crusafont, 1979); Ampudia 9 (Alvarez and García, 1986)). In addition, in Austria, Megacricetodon minutus was reported from the Level of $\mathrm{Vö}-$ sendorf which has yielded Hippotherium and is assigned to Zone MN9 (Daxner-Höck, 1996). Daams and Freudenthal (1988) consider M. minutus a junior synonym of $M$. debruijni. In Germany, M. debruijni was reported from the Level Hammerschmiede (Mayr and Fahlbusch, 1975). These Austrian and German levels may be correlative with the Spanish localities of Can Ponsic 1, Nombrevilla and Pedregueras $2 \mathrm{~A}$ and $2 \mathrm{C}$, and with the French locality of Castelnou 1B (Aguilar et al., 1991). 


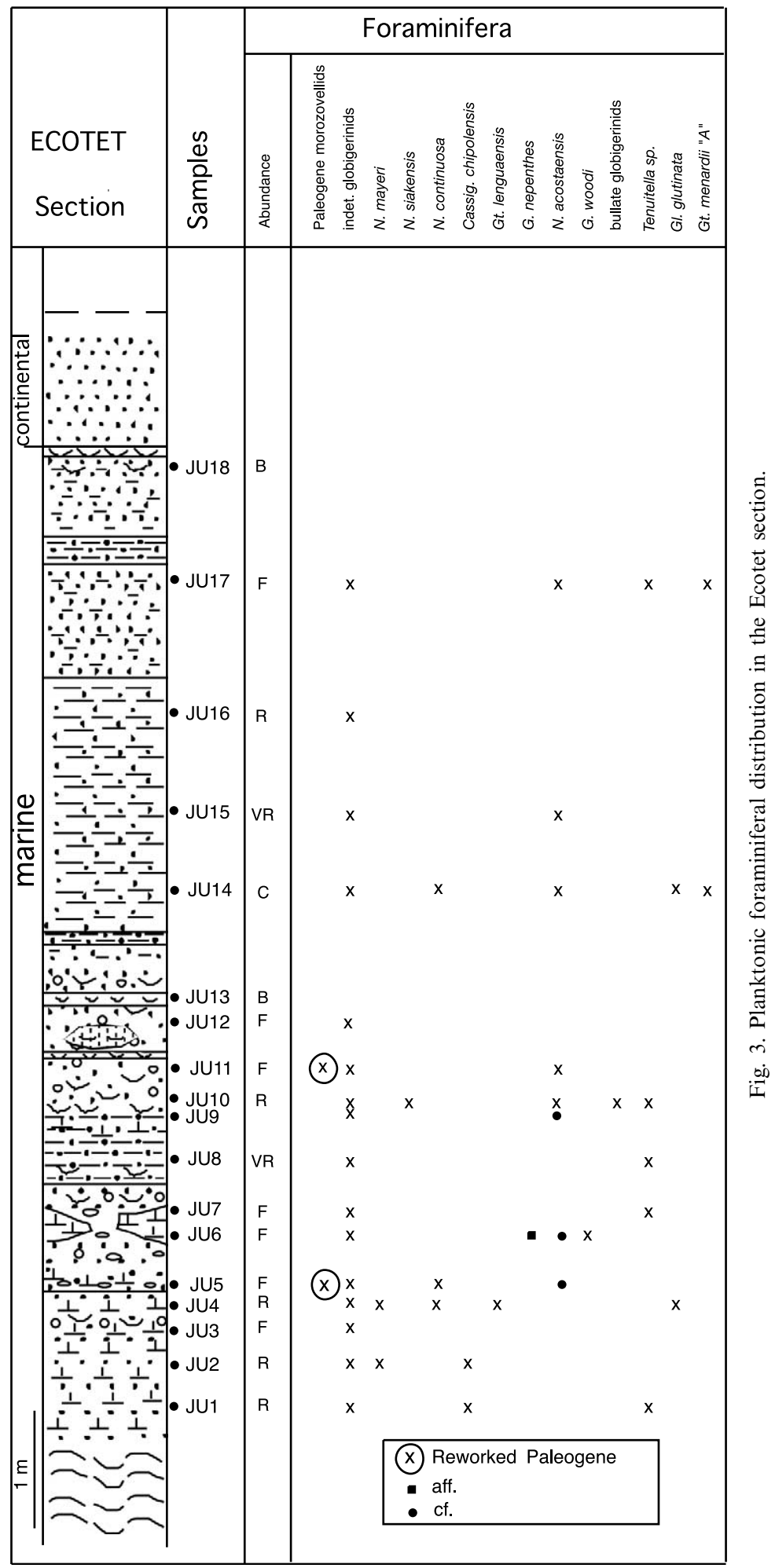




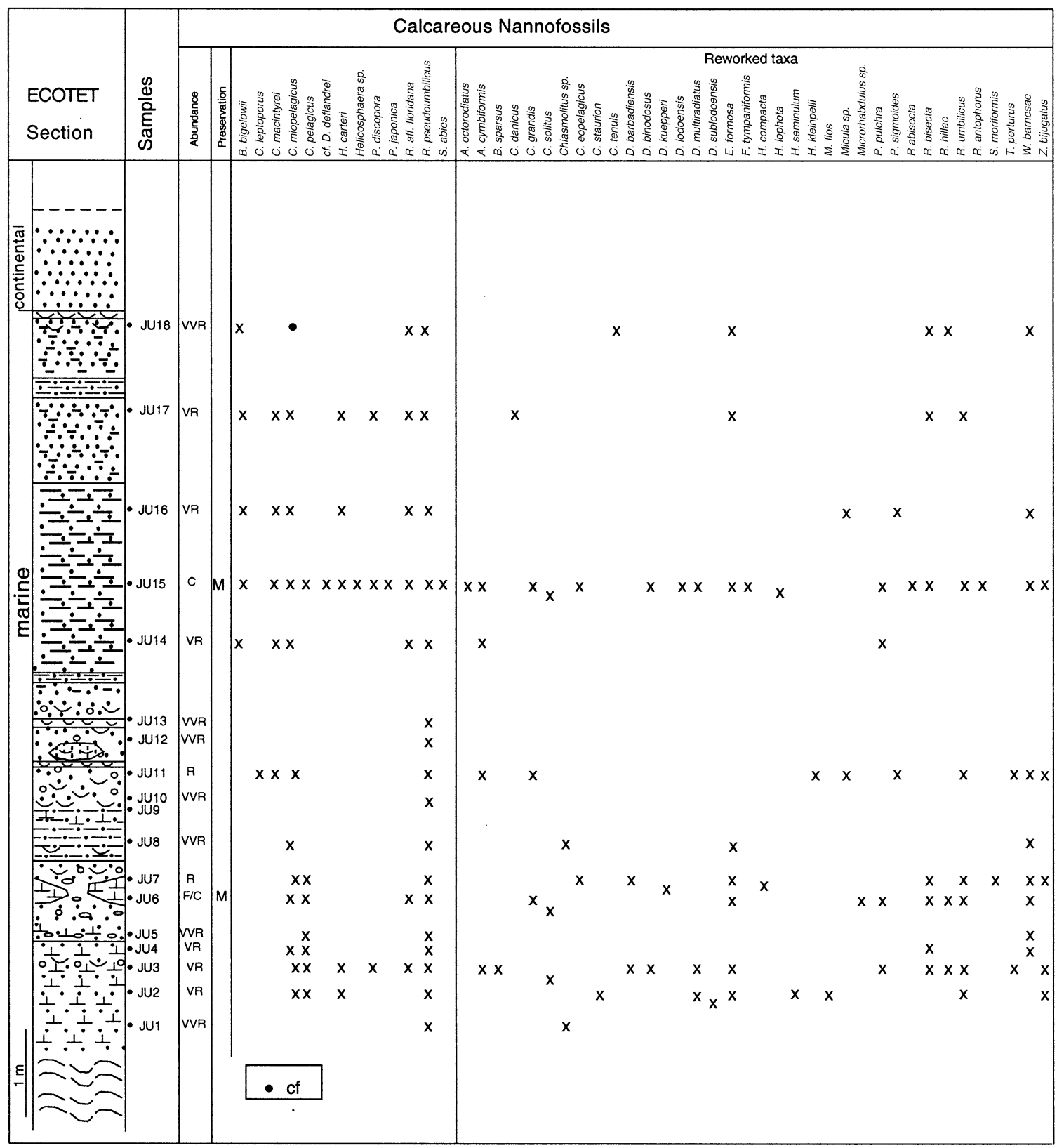

Fig. 4. Calcareous nannoplankton distribution in the Ecotet section. The occurrence of reworked taxa is given to show that the frequency of Neogene taxa is not correlated with that of reworked Paleogene taxa, implying that the Neogene taxa are likely in situ.

Thus, based on the occurrence of Democricetodon cf. nemoralis (Level JUM1) and Megacricetodon debruijni (Levels JMU1 and 2), the upper part of the Ecotet section belongs to Zone MN9.

\subsubsection{Plankton stratigraphy}

Eighteen samples (Figs. 3 and 4) were examined for both foraminifera (planktonic and benthic) and calcareous nannofossils. 


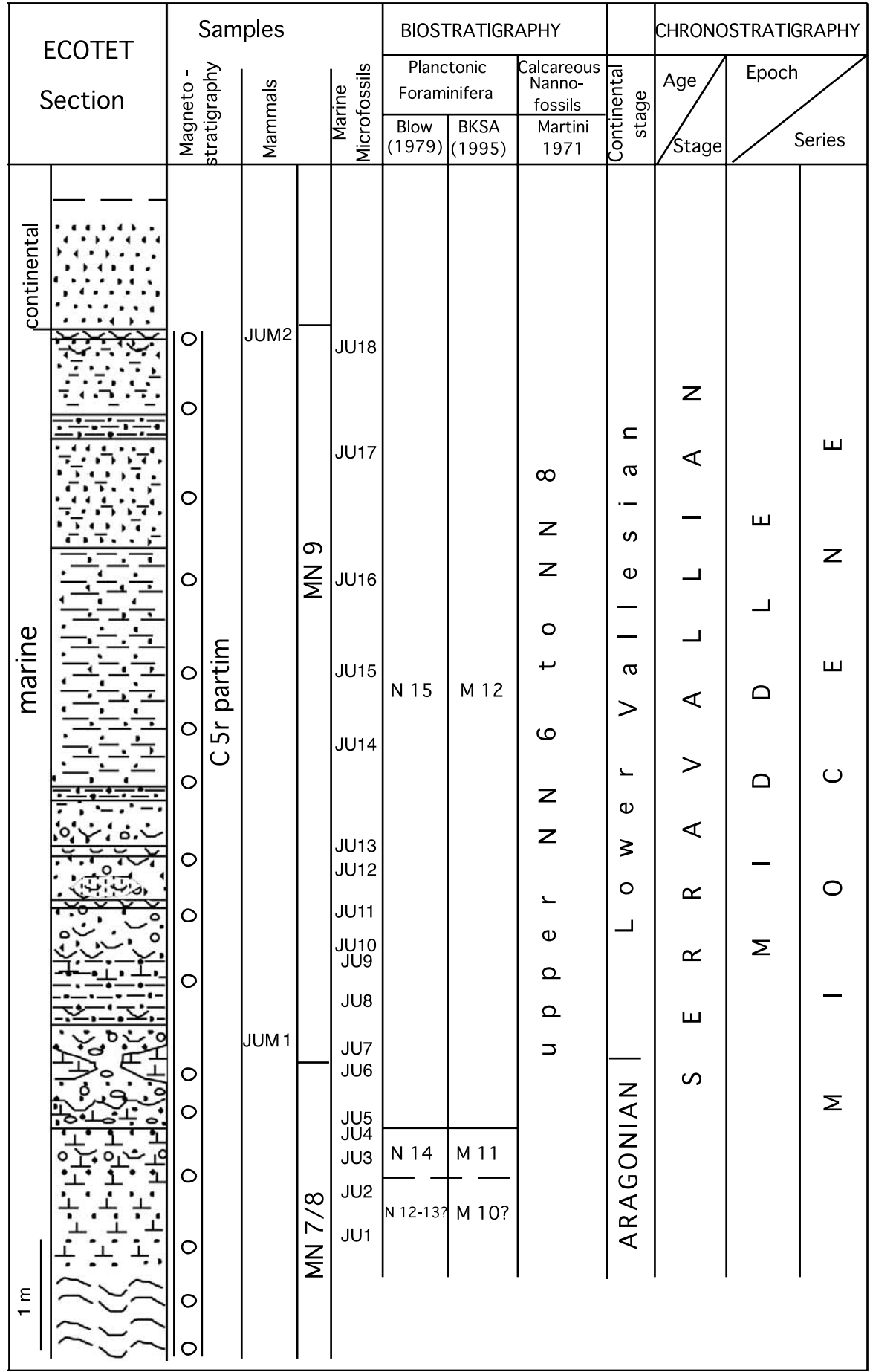

Fig. 5. Magnetobiostratigraphic correlations in the Ecotet section and chronostratigraphy. 
3.3.2.1. Foraminifera. Foraminifera are rare, particularly planktonic forms, and extensive searching was required in order to obtain adequate specimens for identification. When found, most specimens are immature and difficult, if not impossible, to identify with certainty to species level. Benthic foraminifera indicate deposition in a shallow/neritic environment (probably $<50 \mathrm{~m}$ water depth) in addition to Ammonia beccarii, taxa belonging to the genera Bolivina, Cassidulina, Cibicides, Elphidium, Discorbis, Nonion, Textularia, and Valvulineria are scattered throughout the section. The results of our investigation are summarized below.

(1) Cassigerinella chipolensis has its highest occurrence (HO) near the base of Zone N14 (= M11 of Berggren et al., 1995) and was not found above sample JU2 in this section. Its presence in samples JU1 and 2 (near the base of the section; Fig. 3) indicates that the lower part of the section is probably not younger than Zone N12/13 (= Zone M10) or than late-middle Miocene (late Serravallian Age).

(2) The concurrence of Globorotalia lenguaensis and Paragloborotalia mayeri in sample JU4 suggests that this level is assignable to Zone N14 (=Zone M11). The former taxon has its LO at the base of Zone N14 (= Zone M11), whereas the latter taxon has its $\mathrm{HO}$ at the top of Zone N14 (=Zone M11). The sample is correlated with the upper part of the middle Miocene (upper Serravallian Stage).

(3) Specimens resembling Neogloboquadrina acostaensis occur sporadically from sample JU5 through sample JU9. Small, but definitive specimens of $N$. acostaensis are present in sample JU10 and continue sporadically through sample JU17. The LO of $N$. acostaensis defines the base of 'Zone N16' (= Zone M13a; but is not definitive of Zone N16 s.s.; see discussion below). Sample JU5-9 and the remainder of the section is referred to Zone N15 (= Zone M12). Zone N15 (= Zone M12) is restricted to the middle Miocene (Serravallian Stage).

(4) The presence in sample JU17 of the 5-chambered Globrotalia menardii 'A', typical of the upper-middle to lower-upper Miocene (Zones N14-N16; Zones M11-M13a) supports the zonal determination/age estimate made here on the upper part of the section.

(5) Other faunal elements provide no definitive information on zonal assignment/age estimation of this section.

(6) Penecontemporaneous reworking of planktonic foraminifera is not apparent; preservation is uniform and reflects the contemporary sediment lithology. Instances of rare reworking of Paleogene taxa are apparent in the form of chalky (white) tests, a reflection, apparently, of extant Paleogene lithologies.

(7) While it is impossible to determine whether the section is stratigraphically continuous, or contains stratigraphic unconformities/hiatuses, it is assumed to be continuous until demonstrated otherwise and to represent a relatively short interval of time $(\sim /<1 \mathrm{myr})$ spanning the late-middle Miocene Epoch (late Serravallian Age, 12-11 $\mathrm{Ma})$. The reason for this determination is discussed below.

\subsubsection{Calcareous Nannoplankton. Neogene} calcareous nannofossil specimens are scarce to few at all levels except in sample JU15 where they are common (Fig. 4). Placoliths of the Reticulofenestra pseudoumbilicus group, well preserved, are dominant in all assemblages.

Cretaceous and Paleogene (Paleocene and Eocene) nannofossils are present in almost all samples, being common and diverse in some samples (JU2, 15). No species indicative of the reworking of Oligocene, lower or lower-middle Miocene strata have been observed. Noteworthy is the absence to Reticulofenestra floridana, a species usually common in lower Miocene assemblages. Also, it is important to note that the diversity of the Neogene assemblages, presumed autochthonous, is not correlated with the frequency and diversity of allochthonous forms (e.g. compare the composition of the assemblages in samples JU14, 16, 17; Fig. 4). Thus there is no a priori reason to suspect that the Miocene coccoliths are reworked.

Our age determination is based on consistent occurrences and the thorough scan of smear slides $\left(\sim 350 \mathrm{~mm}^{2}\right)$. Because of the scarcity of coccoliths, quantitative analysis would be rather meaningless. For instance, well preserved coccoliths of 
Calcidiscus macintyrei which are doubtless in situ, were not encountered in every preparation.

Only long-ranging taxa occur at Ecotet. A biozonal assignment is not possible, but the consistent occurrence of large, characteristic specimens of Coccolithus miopelagicus constrains the youngest age of the section. At North Atlantic Site 608 (Gartner, 1992; Olafsson, 1991) and Ceara Rise Site 926 (Backman and Raffi, 1997), the HO of $C$. miopelagicus is an abrupt event that occurs well below the LO of Discoaster hamatus. Indeed, in the absence of Catinaster coalitus, whose LO defines the base of Zone NN8, the HO of C. miopelagicus is used to approximate the NN7/NN8 zonal boundary (e.g. (Marino and Flores, 2002)). In Mediterranean sections the $\mathrm{HO}$ of $C$. miopelagicus is difficult to determine because of scattered occurrences above its highest level of common occurrence (HCO) (Hilgen et al., 2000; Sprovieri et al., 2002). Considering the scarcity of coccoliths in the Ecotet section, it is most unlikely that the consistent occurrence of the species in the section corresponds to its range above its HCO. The HCO of $C$. miopelagicus in the Mediterranean and its HO/LAD (Last Appearence Datum) elsewhere are unambiguously older than the $\mathrm{LO} /$ FAD of D. hamatus (Backman and Raffi, 1997; Hilgen et al., 2000; Sprovieri et al., 2002), i.e. older than Zone NN9. Thus, unless all coccoliths are reworked in the Ecotet section, for which there is no evidence, the section is older than Zone NN9. The absence of Reticulofenestra floridana, whose HCO lies in Zone NN6 (Hilgen et al., 2000; Sprovieri et al., 2002; Raffi et al., 1995; Maiorano and Monechi, 1998), further restricts the age of the Ecotet section to the upper NN6lower NN8 zonal interval.

3.3.2.3. Discussion. Recent investigations on integrated astro- and magnetobiostratigraphy of the middle Miocene of the Mediterranean and North Atlantic have a significant bearing on the correlations suggested in this paper.

3.3.2.3.1. Mediterranean. Hilgen et al. (2000) have recently developed an integrated biostratigraphic and astronomical chronology for the Monte Giblescemi section on Sicily. This section spans the middle/late Miocene (Serravallian/Tortonian) boundary. Of significance are the following data.

(1) The LO/FAD of small '4-chambered forms' of Neogloboquadrina (Neogloboquadrina acostaensis s.1.), dated at $11.781 \mathrm{Ma}$. This morphotype ranges in low numbers to $11.546 \mathrm{Ma}$, occurs only sporadically for the next $\sim 0.386 \mathrm{myr}$, and then constitutes a major constituent of subsequent faunas at $11.178 \mathrm{Ma}$. The FAD of $N$. acostaensis, customarily used to denote the middle/late (Serravallian/Tortonian) Miocene boundary, is thus dated astronomically at $11.781 \mathrm{Ma}$, predating its (migratory) appearance at low latitudes in the Atlantic by $\sim 2$ myr. This age estimate is close to that estimated for the FAD of Globoturborotalita nepenthes (11.8Ma (Berggren et al., 1995)) at low latitude Atlantic locations.

(2) The First Common Occurrence (FCO) of Neogloboquadrina acostaensis, dated astronomically at 10.554 Ma.

(3) The disjunt occurrence of Neogloboquadrina acostaensis s.l. (small, 4-chambered forms) and $N$. acostaensis s.s., which may well account for the discrepant records of $N$. acostaensis in the literature and the different levels at which the Serravallian/Tortonian boundary is placed by various investigators (see also Hilgen et al., 2000: 207). The fact that the N15/16 (M12/13) boundary is placed within/linked with (calcareous nannoplankton) Zones NN7, NN8, and NN9 is further evidence in support of this suggestion.

(4) The biostratigraphic location of the base of the Tortonian stratotype at/near the FCO of Neogloboquadrina acostaensis s.s., thus dated astronomically at $10.554 \mathrm{Ma}$.

(5) The HO/LAD of Paragoborotalia mayeri, dated astronomically at $11.205 \mathrm{Ma}$.

(6) The age of the top of the Serravallian stratotype section estimated at $11.8 \mathrm{Ma}$, suggesting that there is a stratigraphic gap between the top of the Serravallian stratotype and the base of the Tortonian stratotype.

More recent studies on integrated calcareous plankton astrochronology of the Mediterranean middle Miocene (Sprovieri et al., 2002) support the studies of Hilgen et al. (2000). Relevant datum events include: 
(1) the LAD of Paragoborotalia mayeri dated at $12.14 \mathrm{Ma}$;

(2) the FAD of Neogloboquadrina acostaensis dated at $11.8 \mathrm{Ma}$;

(3) the LCO of Paragloborotalia siakensis dated at $11.24 \mathrm{Ma}$;

(4) the LAD of Paragloborotalia siakensis dated at $11.21 \mathrm{Ma}$.

Astronomical age estimates of the FAD of small Neogloboquadrina acostaensis s.1. (11.8 Ma) and the LAD of Paragloborotalia mayerilsiakensi $(11.2 \mathrm{Ma})$ are consistent at Gibliscemi (Hilgen et al., 2000), Pelacani and S. Nicola sections (Sprovieri et al., 2002). In Hole 608 this latter event is associated with a normal event identified as Chron C5r.2n, with an estimated age of $\sim 11.5$ Ma (Berggren et al., 1995). At 11.2 Ma P. mayeri disappeared from the Mediterranean and from the North Atlantic (Rockall Plateau, DSDP Site 116) within Biochron NN7. Comparison of the relative position of $P$. mayeri (LAD) with respect to the LAD of Coccolithus miopelagicus at North Atantic ODP Site 608 (Gartner, 1992) (just below the base of Chron $\mathrm{C} 5 \mathrm{n}$ ) and its last common occurrence (LCO) in the Mediterranean (Gibliscemi) (Hilgen et al., 2000) suggests that $P$. mayeri disappeared from the Mediterranean and North Atlantic essentially simultaneously. Chaisson and Pearson (1997), however, note an estimated (astrochronologically) 'tuned' age of $10.49 \mathrm{Ma}$ at western tropical Atlantic ODP Site 925 (Ceara Rise), North Atlantic Ocean

DSDP Site 608 is located at $\sim 43^{\circ} \mathrm{N}, 23^{\circ} \mathrm{W}$ in $\sim 3500 \mathrm{~m}$ water depth (Miller et al., 1986). It was, and remains, one of the best deep sea sites in terms of Miocene bio- and isotope stratigraphy (Miller et al., 1991; Gartner, 1992) and magnetostratigraphy (Clement and Robinson, 1986; Miller et al., 1986). We have restudied the planktonic foraminifera of a part of the middle and upper Miocene stratigraphic record (cores 25-32) of Hole 608; together with the calcareous nannoplankton biostratigraphy reported at this site (Gartner, 1992) they furnish a biostratigraphic record that spans the middle Miocene (lower Serravallian) to lower-upper Miocene (lower Tortonian). Events relevant to our investigations at Ecotet include:
(1) LO of Globoturborotalita nepenthes at $257.25 \mathrm{~m}$ : Chron C5r.3r (11.0 Ma) in Zone NN7;

(2) HO of Paragloborotalia mayeri at $250.14 \mathrm{~m}$ : Chron C5r.2n (11.5 Ma) in Zone NN7;

(3) LO of small Neogloboquadrina acostaensis (rare) at 246.84: Chron C5r.2r (11.4Ma) in Zone NN7.

In summary, then, the following conclusions can be drawn from the above studies.

(1) The LO of small, rare forms of Neogloboquadrina acostaensi s.l. lies in the Mediterranean and North Atlantic in Chron C5r, 1 myr prior to its FCO at $\sim 10.54 \mathrm{Ma}$ (near the base of the Tortonian Stage).

(2) The LO/FAD of Globoturborotalita nepenthes is situated in early Chron C5r (11.8 Ma) in both the Mediterranean and North Atlantic and there is temporal juxtaposition of the earliest occurrences of Neogloboquadrina acostaensis s.l. and Globoturborotalita nepenthes.

(3) The HO of Paragloborotalia mayeri appears to be restricted to Chron C5r over the interval of 11.2-11.5 Ma.

(4) Caution should be used in assigning samples bearing Neogloboquadrina acostaensis automatically to the late Miocene (Tortonian). The earliest forms appear within Zone NN7, whereas the FCO occurs within Zone NN9.

(5) Based on the occurrence of small, rare forms of Neogloboquadrina acostaensis in Ecotet, in close stratigraphic juxtaposition with Paragloborotalia mayeri $(\mathrm{HO}=\mathrm{N} 14 / 15)$ and Cassigerinella chipolensis $(\mathrm{HO}=\mathrm{N} 12 / 13)$, it is reasonable to assign the section at Ecotet to the Chron C5r interval >11 Ma) (see Berggren et al., 1995, fig. 5).

This conclusion is supported by calcareous nannofossil stratigraphy at North Atlantic Site 608, where the $\mathrm{HO}$ of Coccolithus miopelagicus, in Zone NN8, is located in an interval with reverse polarity identified as Chron C5r.1r (Gartner, 1992; Clement and Robinson, 1986). The HO of C. miopelagicus is suspected to be diachronous, however (Berggren et al., 1995; Backman and Raffi, 1997), occurring in Chron C5n.2n in the equatorial Pacific. In sections where calcareous nannoplankton datums have been astrochronologically tuned, the $\mathrm{HO}$ of $C$. miopelagicus has been consistently dated as older than the FAD 
of Discoaster hamatus, itself tied to Chron C5n (Raffi et al., 1995). This implies that sections with $C$. miopelagicus and reverse polarity cannot be younger than Chron C5r. Backman and Raffi (1997) have determined an astrochronologic age of $10.941 \mathrm{Ma}$ for the LAD of C. miopelagicus, an event that Hilgen et al. (2000) remark to be near synchronous between the Mediterranean (HCO dated astronomically at $10.997 \mathrm{Ma}$ ) and Atlantic Sites 608 and 926. On this basis, and within the constraints of planktonic foraminiferal chronology, we confidently interpret the reverse polarity in the Ecotet section as Chron C5r.

\section{Alternative correlation of polarity chrons}

The micromammal faunas from Ecotet are probably synchronous with those of Can Ponsic 1, Pedregueras 2C, Nombrevilla, Vösendorf and Castelnou 1B, and perhaps slightly older than those of Can Llobateres 1 assigned to Zone MN9 (de Bruijn et al., 1992; Agustí et al., 1996). Horizon JUM 1 (lower mammal-bearing level) is correlative with Biozone N15, whereas horizon JUM 2 (upper mammal-bearing level) is correlative with the lower part of Zone N16, the whole section being of reverse polarity and older than the LAD of Coccolithus miopelagicus, an event located in Zone NN8 and Chron C5r (Fig. 5). This leads us to propose an alternative interpretation regarding the magnetostratigraphic location of the Can Llobateres localities. Garcés et al. (1996) and Agustí et al. (1996) have proposed a correlation of these localities with Chron C4Ar.3r (Can Llobateres 1) and Chron C4Ar.2n (Can Llobateres 2). Based on the direct correlations between magnetostratigraphy, plankton stratigraphy and mammal stratigraphy in the Ecotet section, it would seem reasonable to correlate Can Llobateres 1 with Chron C5r.3r and Can Llobateres 2 with Chron C5r.2n. This would re-

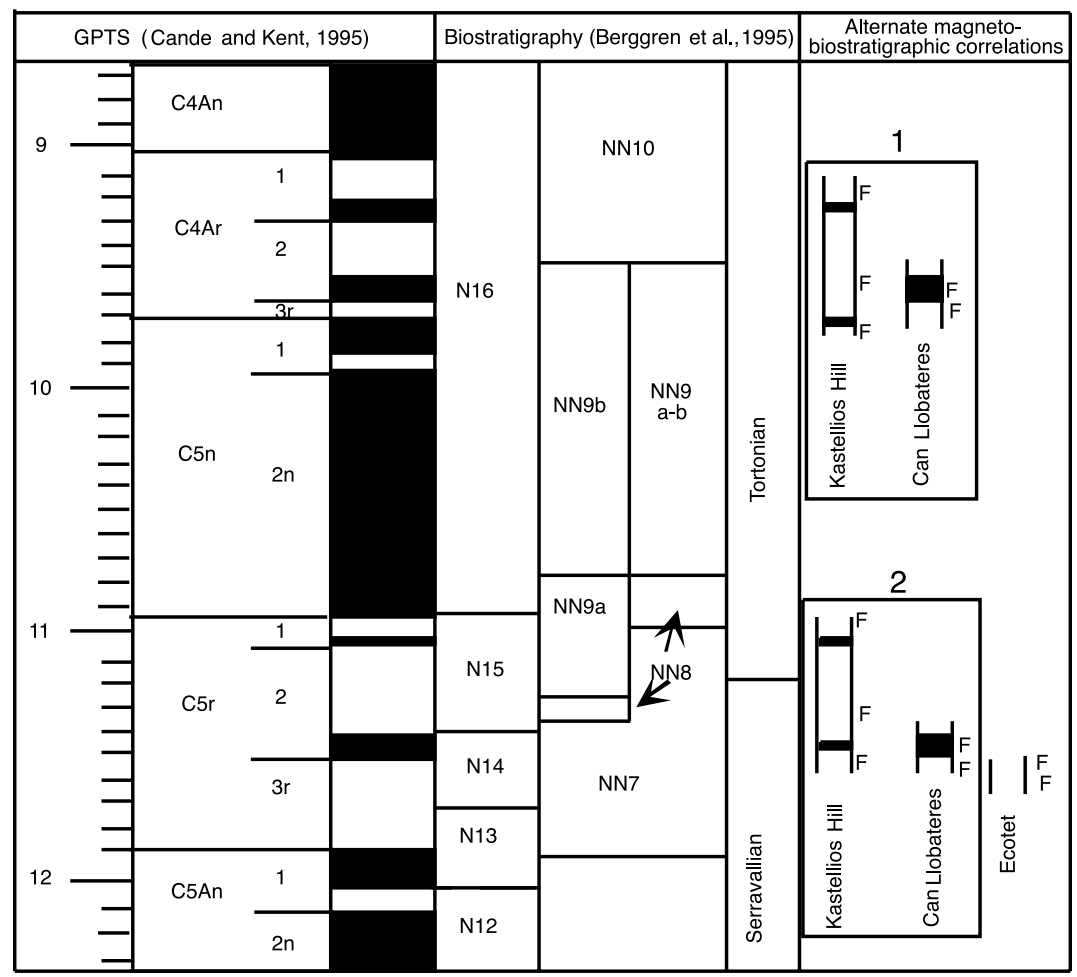

Fig. 6. Alternate magnetobiostratigraphic correlation of Kastellios Hill and Can Llobateres 1 and 2 sections; our preferred correlation of the Ecotet section with Chron C5r.3r is shown in lower panel (option 2). 
sult in the localities of Can Llobateres being 2 myr older than currently thought. We show the two alternative interpretations of the Can Llobateres 1 and 2 and Kastellios sections and our preferred correlation of the Ecotet section with Chron C5r.3r in Fig. 6.

The sections of Kastellios and Bou Hanifia pro parte may be correlated with Chron C5r partim. Such a conclusion agrees with the initial attribution to Chron 10 (LaBrecque et al. (1977)) of the two sections as proposed by Sen (1990). The key element (FAD of Neogloboquadrina acostaensis in earliest Chron C5n) of correlation that was used to locate the section of Kastellios in Chron C4Ar does not hold any longer since this form is now found in Chron C5r.

\section{Conclusions}

The results of our investigation of the Ecotet section permit us to establish a direct correlation between magnetostratigraphy and marine (planktonic foraminifera and calcareous nannofossil) and terrestrial (mammal) biostratigraphies for the middle-late Miocene. Ecotet is not younger than calcareous nannoplankton Zone NN8 and Chron C5r, is referable to planktonic foraminiferal Zones N14 and N15 (M11 and M12), and to the Serravallian Stage (middle Miocene). The micromammal fauna at this locality yields elements that are characteristic of Zone MN9. Levels JUM 1 and 2 may be correlative with, or slightly older than, the level of Can Llobateres 1, also assigned to Zone MN9. The occurrence of rare, small Neogloboquadrina acostaensis in astronomically dated levels as old as $11.8 \mathrm{Ma}$ at several localities in the Mediterranean and in the younger part of Chron C5r at ODP Site 608 allows an alternative correlation for middle Miocene marine-terrestrial stratigraphies in Europe. Consequently, the magnetostratigraphic correlations of the Aragonian/ Vallesian boundary by Agustí et al. (1996, 2001), Garcés et al. (1996), and Krijgsman et al. (1996) can be reinterpreted and considered to be older. Can Llobateres 1 may be correlated with Chron C5r so that the earlier chronostratigraphic interpretations of the Kastellios and Bou Hanifia sections (as correlative with Chron C5r) are upheld.

\section{Acknowledgements}

M.P.A. and W.A.B. are indebted to Jan Wilhem Zachariasse for providing samples from Kastellios Hill and for discussing the taxonomy of Neogloboquadrina acostaensis and the interpretation of the Kastellios Hill section. W.A.B. is grateful to Khaled Ouda for lending his original picked slides from Bou Hanifia. We thank L.J. Flynn and an anonymous reviewer for their thoughtful reviews of this manuscript. This is ISEM (UMR 5554) Contribution No. 2003-047, WHOI Contribution No. 11010 (W.A.B.) and LDEO Contribution No. 6512 (D.V.K.).

\section{Appendix 1. Bou Hanifia (Algeria)}

A species of Hippotherium has been recorded in association with Progonomys cathalai from a level situated $\sim 100 \mathrm{~m}$ above a volcanic tuff dated at $12.03 \pm 0.25 \mathrm{Ma}$ near the base of the Bou Hanifia Formation in NW Algeria (Ameur et al., 1976; see also Woodburne et al., 1996, p. 130). The tuff date has no bearing on the age of the Hippotherium Datum (or the age of the occurrence of Progonomys cathalai) other than providing a maximum age in this section for these occurrences. These tuffs are associated with planktonic foraminiferal faunas assigned to a level 'stratigraphically younger than the base of Zone N14', i.e. Zone N15 (Blow, 1969, 1979) by Ouda and Ameur (1978) based on: (1) the presence of Globigerina nepenthes ( $\mathrm{LO}=\mathrm{Zone} \mathrm{N} 14)$; (2) the absence of Paragloborotalia siakensis $(\mathrm{HO}=\mathrm{N} 14 / 15$ boundary); and (3) the absence of Neogloboquadrina acostaensis ( $\mathrm{LO}=\mathrm{N} 15 / 16$ boundary). Ouda and Ameur (1978, p. 415) refer the upper part of the underlying Anaseur Formation to a level at or near the N13/N14 zonal boundary based on the cooccurrence of e.g. Paragloborotalia mayeri, $P$. siakensis, Globigerina druryi, orbulinids and globoquadrinids. The overlying Bou Hanifia Formation was assigned to Zone N15 (and correlated 
with the base of the stratotype Tortonian) based on the presence of Globigerina nepenthes and the absence of druryi-nepenthes intergrades and $P$. mayeri.

Berggren et al. (1985) and Steininger et al. (1996) concurred with this age assignment. However, a more careful reading of the faunal list provided by Ouda and Ameur (1978, p. 415) reveals that Paragloborotalia mayeri is recorded together with Globigerina nepenthes in the lower part of the Bou Hanifia Formation. An unconformity (with an associated hiatus of about 0.8 myr) was suggested to separate the two lithic units and to essentially span the interval represented by Zone N14. While this may ultimately prove to be correct, we are of the opinion that (at least the lower part of) the Bou Hanifia Formation belongs to Zone N14 (=Zone M11) (Berggren et al., 1995) (and is correlative with the upper part of the Serravallian Stage) for the following reasons. First, $P$. mayeri and $P$. siakensis are generally regarded as taxonomically virtually indistinguishable, if not identical (Bolli and Saunders, 1985; Berggren, 1993) and the concurrent range of $P$. mayeri and $G$. nepenthes forms the basis for the definition of Zone M11 (= Zone N14) (Berggren et al., 1995). Second, both morphotypes have their $\mathrm{HO}$ at the N14/N15 boundary. Thus, the biozonal determination of Bou Hanifia need not necessarily be constrained to Zone N15 but could be as old as Zone N14 (in which the overlap of $G$. nepenthes and $P$. mayeri/siakensis occurs). We (W.A.B.) have been able to confirm the identifications by Ouda and Ameur (1978) by reexamining the original slides upon which their study was made (September 2002). Third, the estimated magnetobiochronologic age for the FAD of $G$. nepenthes is $11.8 \mathrm{Ma}$ (Berggren et al., 1995, pp. $161,175)$. This is consistent with the age estimates of 11.76 Ma and 11.53 Ma for this event in Japan and in Italy, respectively, based on sedimentation accumulation rates interpolated between ages on bracketing tuffs (Odin et al., 1997, p. 399). An age of $12.03 \pm 0.25 \mathrm{Ma}$ is more consistent with a level within Zone N14 (= Zone M11) than within Zone N15 (= M12), which would be correlative with Chron C5r. Thus, the mammalian faunas of Bou Hanifia are younger (by some indeterminate amount recorded in $100 \mathrm{~m}$-thick deposits) than the estimated age of $11.8 \mathrm{Ma}$ for the N14/15 zonal boundary. An age of $12.03 \pm 0.25 \mathrm{Ma}$ is more consistent with a level within Zone N14 (= Zone M11) than within Zone N15 (= M12) which would be correlative with Chron $\mathrm{C} 5 \mathrm{r}$. The recently determined IMBS of Berggren et al. (1995) yields an age estimate of $11.7 \mathrm{Ma}$ for the base of Zone N14 (=FAD G. nepenthes) and 11.4 Ma for the N14/15 boundary (LAD of P. mayeril siakensis). The radioisotopic age of $12.03 \mathrm{Ma}$ on the lower part of the Bou Hanifia Formation (associated with planktonic foraminiferal faunas probably referable to Zone N14; cf. Berggren et al., 1995; Steininger et al., 1996) is seen to be only marginally older than the estimated age of 11.7 Ma for the base of Zone N14 (and thus not considered inconsistent with this estimate). Sen (1990) interpreted the mixed magnetic polarity pattern associated with the mammal-bearing beds of the Bou Hanifia Formation as correlative with Chron $\mathrm{C} 5 \mathrm{r}$ and this is consistent with the interpretation of the section here.

\section{Appendix 2. Kastellios Hill Section (Greece)}

This section contains planktonic foraminifera (Level K4) interbedded with mammal horizons. Hippotherium was found alone in Level $\mathrm{K} 2$ and associated with Progonomys in Level K1 and K3 (de Bruijn et al., 1971; de Bruijn and Zachariasse, 1979). Level K4 was assigned to lower Zone N16 (de Bruijn et al., 1971) based on the association of Globorotalia acostaensis, G. gigantea and G. siakensis. It has yielded a good magnetostratigraphic record (Sen et al., 1986). The long (88 $\mathrm{m})$ reverse magnetic polarity interval with two short $(\sim 1 \mathrm{~m}$ thick) normal events at $\sim 5 \mathrm{~m}$ and $73 \mathrm{~m}$ above the base of the section was assigned to Chron C5r. The age estimate of this section was between $11.47 \mathrm{Ma}$ and $10.30 \mathrm{Ma}$ (but more probably between $10.99 \mathrm{Ma}$ and $10.30 \mathrm{Ma}$ based on the then extant geochronologies of Lowrie and Alvarez (1981) and Harland et al. (1982).

A reexamination of the Kastellios Hill section based on new collections of mammals and planktonic foraminiferea led de Bruijn and Zachariasse, 
1979 to reaffirm the assignment of this section to the lower Vallesian and lower Tortonian, respectively. Level 1 was reassigned to (mammal Zone) $\mathrm{MN} 9$ and levels $\mathrm{K} 2$ and $\mathrm{K} 3$ were retained as Zone MN10. Level K4 (just above K3) in the lower part of the section was referred to the lower part of Zone N16. However, the following taxonomic changes were made to earlier determinations of the planktonic foraminifera (de Bruijn and Zachariasse, 1979, p. 224).

(1) Specimens identified earlier (de Bruijn et al., 1971) as Globorotalia siakensis were now identified as Neogloboquadrina acostaensis, this despite the somewhat ambiguous statements regarding identification of G. siakensis in de Bruijn et al. (1971, p. 17) to the effect that 'most of our specimens are rather different from the original pictures of LeRoy: the chambers are less elongated. The specimen figured on our plate 4, Figs. 4a-c resembles LeRoy's figures very well, those of Figs. $2 \mathrm{a}-\mathrm{c}$ and $3 a-c$ fit the variation of our Trinidad material'. Thus it would seem that specimens were confidently identified as G. siakensis in 1971 despite the seemingly contradictory remark/observation that 'most of our specimens are rather different from the original pictures of of LeRoy'. In actual fact it would appear to us that the forms illustrated in de Bruijn et al. (1971, pl. 4, figs. 3a4c) as G. siakensis agree, in fact, more closely with Globorotalia mayeri Cushman and Ellisor (compare the refigured/redrawn holotype in Bolli and Saunders (1985, p. 205, text-fig. 26: 31a-c, from the Globorotalia fohsi fohsi Zone of Trinidad) as differentiated from $P$. siakensis by Iaccarino (1985, p. 309)

(2) Specimens originally (1971) referred to Globigerina druryi were reassigned to either (small sized) Globigerina apertura or juvenile/immature G. nepenthes.

(3) The lone specimen identified as Globorotalia cf. lenguaensis was reassigned to $G$. ventriosa.

The association of Neogloboquadrina acostaensis, N. falconarae and Globorotalia ventriosa in samples K4 and K6 (just below K4) and the absence of Neogloboquadrina humerosa (characteristic of the upper part of Zone N16 and higher stratigraphic levels) was said to indicate/support reference of the lower part of the Kastellios Hill section to the lower part of Zone N16, a reaffirmation of the conclusions of the earlier (de Bruijn et al., 1971) studies.

We would question this interpretation. It would appear to us that the association of planktonic foraminifera at Kastellios Hill is referable to Zones N14 and/or N15 with Paragloborotalia mayeri and $N$. nepenthes and fully correlatable to Chron C5r as shown in Berggren et al. (1985, 1995). We have examined samples K1, K2 and K4 from Kastellios Hill kindly sent by J.-W. Zachariasse but did not find planktonic foraminifera in them. However, samples K1, K2 and K4 have yielded rare to exceedingly rare (sample K4) calcareous nannofossils. Preservation is extremely poor in all three samples which comprise a mixture of equally diverse Paleogene and Neogene species. Unlike in the Ecotet section, the Neogene coccoliths in these three samples are broken and recrystallized, suggesting transport (in agreement with Krijgsman et al. (1996). (However, unlike these authors, we would assert that reworking is pervasive throughout the section and conclude that marine as well as mammal faunas are transported.) Few specimens are identifiable at the species level, in particular among discoasters whose tips are broken. Discoaster deflandrei and D. challengeri are the only discoaster species identified, the former positively, the latter less confidently. Conspicuous in these assemblages of long-ranging species (Calcidiscus macintyrei, Reticulofenestra gr. pseudoumbilicus, Helicosphaera carteri, Umbilicosphaera cricota, Sphenolithus neoabies, Coccolithus pelagicus, Pontosphaera discopora, Braarudosphaera bigelowii, Rhabdosphaera procera) is the absence of typical, large forms of Coccolithus miopelagicus (a couple of small placoliths might be referable to this species). This differentiates significantly the assemblages of Kastellios Hill from those of Ecotet, and indicates that the former are younger than the latter although there is no indication as to the age difference. Scarce placoliths of Reticulofenestra floridana, some well, others poorly preserved, were encountered in all three samples. They may be among the reworked Paleogene species or be reworked with the lowermiddle Miocene species $S$. heteromorphus. If transport has occurred, the calcareous nannofos- 
sils do not date the section itself, but may date the mammal fauna associated with them.

The Kastellios Hill section magnetostratigraphic correlation with the GPTS was thoroughly reviewed by Sen (1996, pp. 59-60). The biostratigraphic association and sequential order of murid rodents and Hippotherium at Kastellios has led to the preference for a younger $(\sim 9 \mathrm{Ma})$ rather than older $(\sim 11 \mathrm{Ma})$ age for their occurrence. The basic support for this interpretation comes from the correlation of the base of Zone N16 (FAD of Neogloboquadrina acostaensis) with the base of Chron C5n (Berggren et al., 1985, 1995)) which is seemingly incompatible with the reverse polarity observed at Kastellios Hill. Steininger et al. (1990) equated the middle/late (Serravallian/Tortonian) boundary with a level within Zone N15 (and Zone NN9) at Chron C5An with an age estimate of $11.5 \mathrm{Ma}$ based on the discredited (Berggren et al., 1985, p. 213) correlation of sea-floor anomaly C5n with magnetic Chron 9, rather than the preferred correlation with magnetic Chron 11. The correlation of Kastellios Hill with Chron $\mathrm{C} 5 \mathrm{r}$ was reaffirmed as well as with base of the Kizilhisar pollen zone of Turkey (Steininger et al., 1990, p. 23).

Kastellios Hill was subsequently correlated with Chron C4Ar and estimated to range from $\sim 9.58$ Ma to $\sim 9.02 \mathrm{Ma}$ (Steininger et al. (1996, p. 35) based on the above reasoning and similar correlations have been made by Sen (1996), Garcés et al., 1996 and Agustí et al. (1996, 2001). However, we would now question this interpretation based on our studies of the Ecotet (Jujurieux) section and a reevaluation of the data from the Kastellios Hill section (above). Based on the revised integrated magnetochronologic scale of Berggren et al. (1995), we can estimate that the genera Progonomys and Hippotherium were present in the Mediterranean area at $\sim 11.6$ and $11.4 \mathrm{Ma}$, respectively.

\section{Appendix 3. LO of the Murinae Progonomys}

Determination of the relative age of the FO of the Murinae Progonomys in Europe requires high resolution sampling. This is a difficult task be- cause of the small number of mammal-bearing localities, their scanty documentation, and their isolation that render geographic distribution essentially unknown, and the near complete lack of expanded sections. In such conditions, the presence/absence of key species is a criterion of limited value, because absence may reflect only preservational bias. More reliable is the comparison of evolutionary stages in specific lineages shared by several localities. Table 2 shows the location of the first occurrence of Murinae with respect to boundaries of zone MN9 in Spain, Southern France and Central Europe. The range of lineages useful for relative dating is shown and the presence of Progonomys is marked. The small numbers of such lineages within a geographic area and between areas is explained by geographical differentiation. The MN Zones are defined based on faunal composition whereas zonal boundaries are delineated on the basis of faunal breaks and lowest and highest occurrences of taxa (that may correspond to immigration or extinction events (Aubry, 1997).

The relative dating of the first occurrence of Murinae in Europe relies on a few sites with Progonomys. These are: Pedregueras 2C (Daams et al., 1988; van Dam, 1997), and Can Llobateres 1 (Can Llobateres 2 discovered long after Can Llobateres 1 , is $10 \mathrm{~m}$ above the level of Can Llobateres 1 (see reference in Agustí et al. (1996), and Castelnou 1B (France) (Aguilar et al., 1991).

\section{Pedregueras 2C (Spain)}

In a fauna comprising $>700$ teeth of rodents (Daams et al., 1988), a single murine $\mathrm{m} 3$ was found and determined as Progonomys hispanicus (van Dam, 1997). The dating of the fauna is based on some representatives of Cricetidae (Hispanomys, Cricetulodon).

\section{Can Llobateres 1 and 2 (Spain)}

Two teeth of a Murinae have been determined as Progonomys cathalai in the fauna of Can Llobateres 1 (Hartenberger and Thaler, 1963; 
Table 2

Distribution chart showing the lineages used for biochronological correlation of Late Aragonian and Vallesian mammal-bearing European localities and relevant for the relative dating of the lower occurrence of Progonomys in Europe
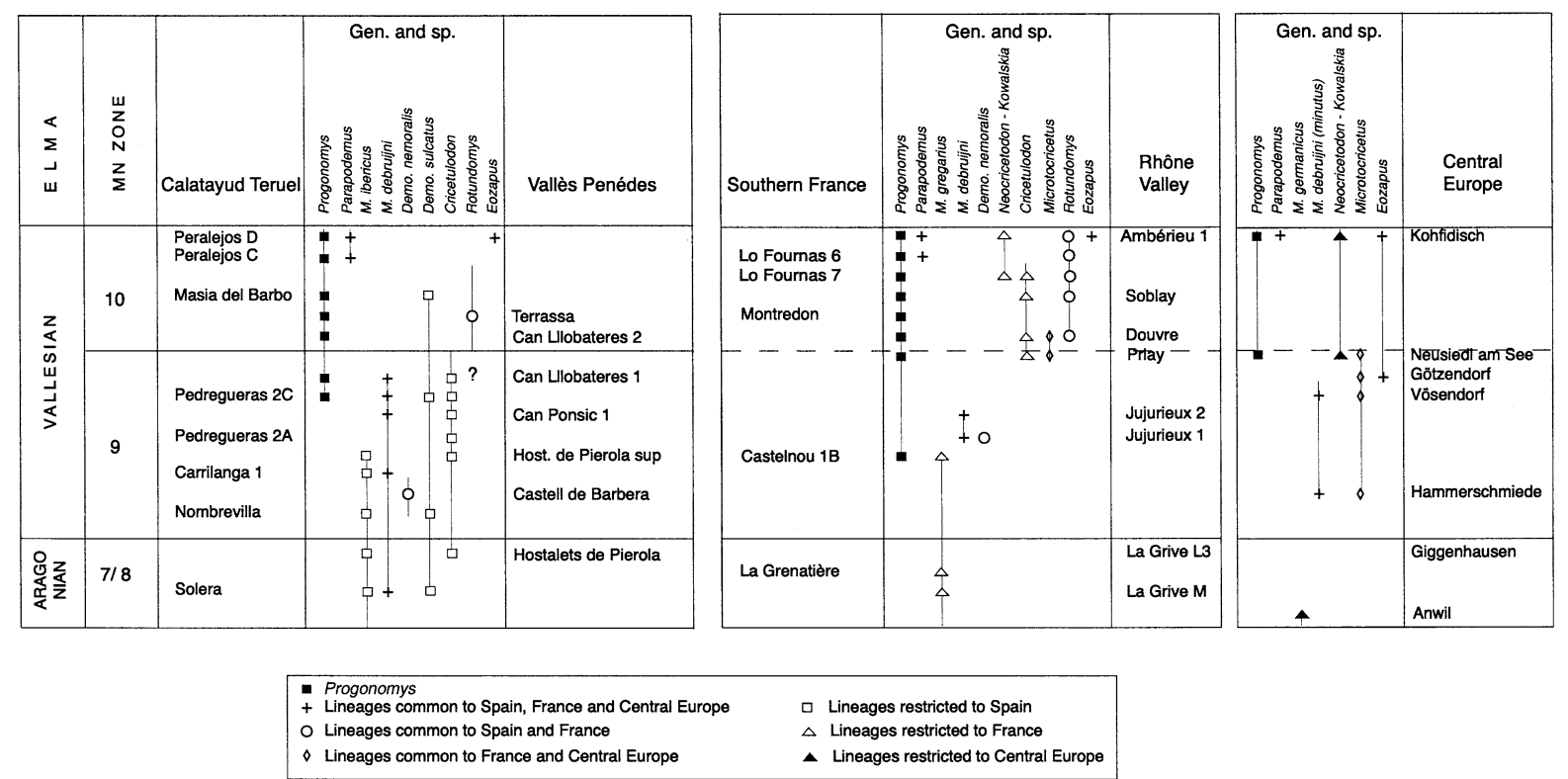

The Ecotet mammal bearing localities are noted as Jujurieux 1 and 2.

Michaux, 1971) which otherwise has yielded $>10000$ teeth of rodents. Several rodent species at Can Llobateres 1 are known to be associated elsewhere with Hippotherium (Cricetulodon Zone) (Agustí and Moyà-Solà, 1991). Teeth of the rodent Cricetulodon are abundant in the Vallès-Penédes and Calatayud-Teruel Basin but are rarely found in the deposits of France and the rest of Europe. Among the few teeth of rodents found in Can Llobateres 2, there were no more than five teeth of Progonomys. Spanish authors assign Can Llobateres 1 to Zone MN9, and Can Llobateres 2 to Zone MN10.

\section{Castelnou 1B (France)}

Progonomys ( $=P$. cf. hispanicus) has been found at Castelnou 1B. Another rodent belongs to the lineage of Megacricetodon gregarius and its stage of evolution indicates a younger age than the localities of La Grive M and La Grenatière. The degree of evolution of $M$. gregarius (splitting of the anteroconid) has reached the stage seen in M. ibericus (or is similar), which belongs to a parallel lineage established in Spain and associated with Hippotherium. Large Megacricetodon are abundant in Aragonian deposits but are also present in the Spanish lower Vallesian (Daams and Freudenthal, 1988). They are unknown in the lower Vallesian of central Europe. Megacricetodon gregarius dates the fauna of Castelnou 1B as younger than La Grive $\mathrm{M}$ and the La Grenatière, and older (or contemporaneous than Can Llobateres 1).

\section{Priay (France)}

At Priay Progonomys cf. cathalai is associated with Cricetulodon and Microtocricetus (Welcomme et al., 1991). The genus Microtocricetus is rather well represented in Zone MN9 in Central Europe; however, it is also reported from Zone MN10 (Rögl and Daxner-Höck, 1996; Mein, 1999). Consequently, Priay can be referred to 
Zone MN9 or Zone MN10. However, it is necessary to recognize that the reports of Progonomys in Zone MN10 in Central Europe are based on the assumption by their authors that Murinae are present only since the beginning of Zone MN10.

The five localities discussed above provide firm elements upon which to assert the presence of Muridae - all referred to the genus Progonomys - in the lower Vallesian. However, Murinae have not been found in all lower Vallesian deposits. It is uncertain whether this signifies a true absence or simply reflects a fossilization bias. It may also be argued that Progonomys was rare for some time after its immigration. The fauna of Castelnou 1B, which includes four cheek teeth of Progonomys out of a total of 127 rodent teeth, would support this claim. Castelnou 1B is a fissure filling. Such deposits usually yield more diversified faunas than river deposits. In conclusion, first, the fauna of Castelnou 1B can be referred to the Spanish lower VallesianCricetulodon Zone (MN9 Zone, contemporaneous with Hippotherium); second, Ecotet (Jujurieux) is referred to Zone MN9 on the basis of Megacricetodon debruijni and Democricetodon nemoralis. The absence of Progonomys at Ecotet (Jujurieux) is interpreted as bias.

\section{References}

Aguilar, J.-P., Calvet, M., Michaux, J., 1991. Présence de Progonomys (Muridae, Rodentia, Mammalia) dans une association de rongeurs de la fin du Miocène moyen (Castelnou 1B, Pyrénées-Orientales, France). Geobios 24, 503-508.

Agustí, J., 1990. The Miocene rodent succession in Eastern Spain: A zoogeographical appraisal. In: Lindsay, E.H., et al. (Eds.), European Neogene Mammal Chronology. Plenum, New York, pp. 375-404.

Agustí, J., Cabrera, L., Garcés, M., Köhler, M., Moyà-Solà, S., Parés, J.M., 1996. Can Llobateres: The pattern and timing of the Vallesian hominoid radiation reconsidered. J. Hum. Evol. 31, 143-155.

Agustí, J., Cabrera, L., Garcés, M., Krijgsman, W., Oms, O., Parés, J.M., 2001. A calibrated mammal scale for the Neogene of Western Europe: State of the art. Earth Sci. Rev. 52, 247-260.

Agustí, J., Moyà-Solà, S., 1991. Spanish Neogene Mammal succession and its bearing on continental biochronology. Newslett. Stratigr. 25, 91-114.

Alvarez, M.A., García, E., 1986. New Gliridae and Cricetidae from the Middle and Upper Miocene of the Duero Basin, Spain. Stud. Geol. Salmanticensia 22, 145-189.

Ameur, R.Ch., Jaeger, J.-J., Michaux, J., 1976. Radiometric age of early Hippotherium fauna in North-west Africa. Nature 261, 38-39.

Anadón, P., Lopez-Martínez, N., Mitjavilla, J.P., Utrilla, R., Vàzquez, A., 1996. New Late Miocene mammal sites correlated with the radiometric scale from the Bicorp Basin (Eastern Spain). Geobios 29, 251-260.

Aubry, M.-P., 1997. Interpreting the (marine) stratigraphic record. In: Aguilar, J.-P., Michaux, J., Legendre, S. (Eds.), Actes du Congrès BiochroM' 97. Mém. Trav. E.P.H.E., Instit. Montpellier, 21, 15-32.

Backman, J., Raffi, I., 1997. Calibration of Miocene events to orbitally tuned cyclostratigraphies from Ceara Rise. In: Shackleton, N.J., et al. (Eds.), Proc. ODP, Sci. Results 154. Ocean Drilling Program, College Station, TX, pp. 83 99.

Berggren, W.A., 1993. Neogene planktonic foraminiferal biostratigraphy of eastern Jamaica. In: Wright, R.M., Robinson, T. (Eds.), Biostratigraphy of Jamaica. Geol. Soc. Am. 182, 179-217.

Berggren, W.A., Kent, D.V., Flynn, J.J., van Couvering, J.A., 1985. Cenozoic geochronology. Geol. Soc. Am. 96, 14071418 .

Berggren, W.A., Kent, D.V., Swisher, C.C., Aubry, M.-P., 1995. A revised Cenozoic geochronology and chronostratigraphy. In: Berggren, W.A., et al. (Eds.), Geochronology, Time Scales and Global Stratigraphic Correlations: A Unified Temporal Framework for an Historical Geology. Soc. Econ. Paleontol. Miner. SP 54, 126 pp.

Blow, W.H., 1969. Late Middle Eocene to Recent planktonic foraminiferal biostratigraphy. In: Brönniman, P., Renz, H.H. (Eds.), Proc. First Internat. Conf. Plankton. Microfoss., Geneva, 1967, 1, 199-422.

Blow, W.H, 1979. The Cainozoic Globigerinida. Brill, Leiden, $1413 \mathrm{pp}$.

Bolli, H.M., Saunders, J.B., 1985. Oligocene to Holocene low latitude planktic foraminifera. In: Bolli, H.M., Saunders, J.B., Perch-Nielsen, K. (Eds.), Plankton Stratigraphy. Cambridge University Press, Cambridge.

Cande, S.C., Kent, D.V., 1995. Revised calibration of the geomagnetic polarity time scale for the Late Cretaceous and Cenozoic. J. Geophys. Res. 100, 6093-6095.

Chaisson, W.P., Pearson, P.N., 1997. Planktonic foraminifer biostratigraphy at Site 925: Middle Miocene-Pleistocene. In: Shackleton, N.J., et al. (Eds.), Proc. ODP, Sci. Results 154. Ocean Drilling Program, College Station, TX, pp. 3-31. Clement, B., Robinson, F., 1986. The magnetostratigraphy of Leg 94 sediments. In: Ruddiman, W.F., et al. (Eds.), Initial Reports DSDP 94, pp. 635-650.

Daams, R., Freudenthal, M., 1988. Megacricetodon (Cricetidae) from the Aragonian and the Lower Vallesian of the Calatayud-Teruel basin. In: Freudenthal, M. (Ed.), Biostratigraphy and Paleoecology of the Neogene Micromammalian Faunas from the Calatayud-Teruel Basin (Spain). Scr. Geol. Spec. Iss. 1, 39-132. 
Daams, R., Freudenthal, M., van der Meulen, A.J., 1988. Ecostratigraphy of micromammal faunas from the Neogene of Spain. In: Freudenthal, M. (Ed.), Biostratigraphy and Paleoecology of the Neogene Micromammalian Faunas from the Calatayud-Teruel Basin (Spain). Scr. Geol. Spec. Iss. 1, 297-302.

Daxner-Höck, G., 1996. Faunenwandel im Obermiozän und Korrelation der MN 'Zonen' mit den Biozonen des Pannons der Zentralen Paratethys. Beitr. Paläontol. Wien, pp. 1-9.

de Bruijn, H., Daams, R., Daxner-Höck, G., Fahlbusch, V., Ginsburg, L., Mein, P., Morales, J., 1992. Report of the RCMNS working group on fossil mammals, Reisenburg 1990. Newslett. Stratigr. 26, 65-118.

de Bruijn, H., Sondaar, P., Zachariasse, W.J., 1971. Mammalia and foraminifera from the Neogene of Kastellios Hill (Crête). A correlation of continental and marine biozones. Proc. Kon. Ned. Akad. Wet. Amst. B 74, 1-22.

de Bruijn, H., Zachariasse, W.J., 1979. The correlation of marine and continental biozones of Kastellios Hill reconsidered. Ann. Géol. Pays Hellén. Athènes, H.S., 219-226.

Demarcq, G., 1973. Lyonnais, Vallée du Rhône, Guides géologiques régionaux. Masson, $175 \mathrm{pp}$.

Flynn, L.J., Barry, J.C., Morgan, M.E., Pilbeam, D., Jacobs, L.L., Lindsay, E.H., 1995. Neogene Siwalik mammalian lineages: Species longevities, rates of change, and mode of speciation. Palaeogeogr. Palaeoclimatol. Palaeoecol. 115, 249-264.

Garcés, M., Agustí, J., Cabrera, L., Parés, J.M., 1996. Magnetostratigraphy of the Vallesian (late Miocene) in the Vallès-Penédes Basin (NE Spain). Earth Planet. Sci. Lett. 142, 381-396.

Gartner, S., 1992. Miocene nannofossil chronology in the North Atlantic, DSDP Site 608. Mar. Micropaleontol. 18, 307-331.

Harland, W.B., Cox, A.V., Llewellyn, P.B., Pickton, C.A.G., Smith, A.G., Walters, R., 1982. A Geologic Time Scale. Cambridge University Press, Cambridge, $131 \mathrm{pp}$.

Hartenberger, J.-L., 1965. Les cricetidae (Rodentia) de Can Llobateres (Néogène d'Espagne). Bull. Soc. Géol. Fr., 7ème sér. VII, 487-498.

Hartenberger, J.-L., Crusafont, M., 1979. Rongeurs miocènes dans le Vallès-Penédes. 1 - Les rongeurs de Can Ponsic. Palaeovertebrata 9, 1-15.

Hartenberger, J.-L., Thaler, L., 1963. Sur les rongeurs fossiles $\mathrm{du}$ Vallésien (Miocène supérieur) de Can Llobateres (Sabadell, Espagne). C. R. Acad. Sci. Paris 256, 3333-3336.

Hilgen, F.J., Krijgsman, W., Raffi, I., Turco, E., Zachariasse, W.J., 2000. Integrated stratigraphy and astronomical calibration of the Serravallian/Tortonian boundary section at monte Gibliscemi (Sicily, Italy). Mar. Micropaleontol. 38, 181-212.

Iaccarino, S., 1985. Mediterranean Miocene and Pliocene planktic foraminifera. In: Bolli, H.M., Saunders, J.B., Perch-Nielsen, K. (Eds.), Plankton Stratigraphy. Cambridge University Press, Cambridge, pp. 283-314.

Kappelman, J., Sen, S., Fortelius, M., Duncan, A., Alpagut, B., Crabaugh, J., Gentry, A., Lunkka, J.P., Mc Dowell, F.,
Solounias, N., Viranta, S., Werdelin L., 1996. Chronology and Biostratigraphy of the Miocene Sinap Formation of Central Turkey. In: Bernor, R.L., et al. (Eds.), The Evolution of Western Eurasian Neogene Mammal Faunas. Plenum, New York, pp. 79-95.

Kirschvink, J.L., 1980. The least-square line and plane and the analysis of paleomagnetic data. Geophys. J. R. Astron. Soc. 62, 699-718.

Krijgsman, W., Garcés, M., Langereis, C.G., Daams, R., van Dam, J., van Der Meulen, A.J., Agustí, J., Cabrera, L., 1996. A new chronology for the middle to late Miocene continental record in Spain. Earth Planet. Sci. Lett. 142, 367-380.

LaBrecque, J.1., Kent, D.V., Cande, S.C., 1977. Revised magnetic polarity time scale for late Cretaceous and Cenozoic time. Geology 5, 330-335.

Lowrie, W., Alvarez, W., 1981. One hundred million years of geomagnetic polarity history. Geology 9, 392-397.

Maiorano, P., Monechi, S., 1998. Revised correlation of Early and middle Miocene calcareous nannofossil events and magnetostratigraphy from DSDP Site 563 (North Atlantic Ocean). Mar. Micropaleontol. 35, 235-255.

Marino, M., Flores, J.A., 2002. Miocene to Pliocene calcareous nannofossil biostratigraphy at ODP Leg 177 Sites 1088 and 1090. Mar. Micropaleontol. 45, 291-307.

Mayr, H., Fahlbusch, V., 1975. Eine unterpliozäne Kleinsäugerfauna aus der Oberen Süsswasser-Molasse Bayerns. Mitt. Bayer. Staatss. Paläontol. Hist. Geol. 15, 91-111.

Mein, P., 1985. A new direct correlation between marine and continental scales in Rhodanian Miocene. Abstracts VIII Congress R.C.M.N.S., Budapest, 377-379.

Mein, P., 1999. The Late Miocene small mammal succession from France, with emphasis on the Rhône Valley localities, in Hominoid Evolution and Climatic change in Europe. In: Agustí, J., et al. (Eds.), The Evolution of Neogene Terrestrial Ecosystems in Europe, vol. 1. Cambridge Univ. Press, Cambridge, pp. 140-164.

Michaux, J., 1971. Muridae (Rodentia) néogènes d'Europe sud-occidentale Evolution et rapports avec les formes actuelles. Paléobiol. Continent. 2, 1-67.

Miller, K.G., Fairbanks, R.G, Thomas, E., 1986. Benthic foraminiferal carbon isotopic records and the development of abyssal circulation in the eastern North Atlantic. In: Ruddiman, W.F., et al. Ed.), Initial Reports DSDP 94, pp. 981996.

Miller, K.G., Feigenson, M.D., Wright, J.D., Clemens, B., 1991. Miocene isotope refercne section, Deep Sea Drilling Project Site 608: An evaluation of isotope and biostratigraphic resolution. Paleoceanography 6, 33-52.

Odin, G.S., Takahashi, M., Coccioni, R., Cosca, M., 1997. Géochronologie de niveaux situés autour de l'apparition de Globigerina nepenthes au Japon et en Italie: âge de la limite Serravallien/Tortonien. In: Montanari, A., Odin, G.S., Coccioni, R. (Eds.), Miocene Stratigraphy: An Integrated Approach. Developments in Palaeontology and Stratigraphy 15, Elsevier, Amsterdam, pp. 395-402.

Olafsson, G., 1991. Quantitative calcareous nannofossil bio- 
stratigraphy and biochronology of early through late Miocene sediment from DSDP Hole 608. Medd. Stockholm Univ. Inst. Geol. Geok. 203 (4), 28 pp.

Ouda, K., Ameur, R.Ch., 1978. Contribution to the biostratigraphy of the Miocene sediments associated with primitive Hippotherium Fauna of Bou-Hanifia, Northwest Algeria. Rev. Esp. Micropal. X 3, 407-420.

Raffi, I., Rio, D., d'Atri, A., Fornaciar, i E., Rochetti, S., 1995. Quantitative distribution patterns and biomagnetostratigraphy of middle and late Miocene calcareous nannofossils from equatorial Indian and Pacific oceans (Legs 115, 130 and 138). In: Pisias, N.G., et al. (Eds.), Proc. ODP, Sci. Results 138. Ocean Drilling Program, College Station, TX, 479-502.

Rögl, F., Daxner-Höck, G., 1996. Late Miocene Paratethys correlations. In: Bernor, R.L. et al. (Eds.), The Evolution of Western Eurasian Neogene Mammal Faunas. Plenum, New York, pp. 47-55.

Sen, S., 1990. Hippotherium datum and its chronologic evidence in the Mediterranean area. In: Lindsay, E.H., et al. (Eds.), European Neogene Mammal Chronology. Plenum, New York, pp. 495-505.

Sen, S., 1996. Present state of magnetostratigraphic studies in the continental Neogene of Europe and Anatolia. In: Bernor, R.L., et al. (Eds.), The Evolution of Western Eurasian Neogene Mammal Faunas. Plenum, New York, pp. 56-63.

Sen, S., 1997a. Magnetostratigraphic calibration of the European Neogene mammal chronology. Paleogeogr. Paleoclimatol. Paleoecol. 133, 181-204.

Sen, S., 1997b. The Oldest Late Miocene Murids from Anatolia and their implications on the biochronology of the Old Word Murids. Résum. BiochroM '97, Montpellier, 14-17 April, p. 95.

Sen, S., Valet, J.-P., Ioakim, C., 1986. Magnetostratigraphy and biostratigraphy of the Neogene deposits of Kastellios Hill (Central Crete, Greece). Palaeogeogr. Palaeoclimatol. Palaeoecol. 53, 321-334.

Sprovieri, R., Bonomo, S., Caruso, A., Di Stephano, A., Di
Stephano, E., Foresi, L.M., Iaccarino, S.M., Lirer, F., Mazzei, R., Salvatorini, G., 2002. An integrated calcareous plankton biostratigraphic scheme and biochronology for the Mediterranean middle Miocene. Riv. Ital. Paleontol. Stratigr. 108, 337-353.

Steininger, F.F, Berggren, W.A., Kent, D.V., Bernor, R.L., Sen, S., Agustí, J., 1996. Circum-Mediterranean Neogene (Miocene and Pliocene) marine-continental chronologic correlations of European mammal units. In: Bernor, R.L., et al. (Eds.), The Evolution of Western Eurasian Neogene Mammal Faunas. Plenum, New York, pp. 7-46.

Steininger, F.F., Bernor, R.L., Fahlbusch, V., 1990. European Neogene marine/continental chronologic correlation. In: Lindsay, E.H., et al. (Eds.), European Neogene Mammal Chronology. Plenum, New York, pp. 15-46.

Swisher III, C.C., 1996. New ${ }^{40} \mathrm{Ar} /{ }^{39} \mathrm{Ar}$ dates and their contribution toward a revised chronology for the Late Miocene nonmarine fauna of Europe and West Asia. In: Bernor, R.L., et al. (Eds.), The Evolution of Western Eurasian Neogene Mammal Faunas. Columbia Univ. Press, New York, pp. 64-771.

van Dam, J.A., 1997. The small mammals from the upper Miocene of the Teruel-Alfambra region (Spain): Paleobiology and paleoclimatic reconstructions. Geol. Ultraiectina $156,1-204$.

Welcomme, J.-L., Aguilar, J.-P., Ginsburg, L., 1991. Découverte d'un nouveau Pliopithèque (Primates, Mammalia) associé à des rongeurs dans les sables du Miocène supérieur de Priay (Ain, France) et remarques sur la paléogéographie de la Bresse au Vallésien. C. R. Acad. Sci. Paris 313, 723-729.

Woodburne, M.O., Bernor, R.L., Swisher III, C.C., 1996. An appraisal of the stratigraphic and phylogenetic bases for the 'Hippotherium' datum in the Old Word. In: Bernor, R.L., et al. (Eds.), The Evolution of Western Eurasian Neogene Mammal Faunas. Plenum, New York, pp. 124-136.

Zijderveld, J.D.A., 1967. AC demagnetization of rocks: Analysis of results. In: Collinson, D.W. et al. (Eds.), Methods in Paleomagnetism, Elsevier, New York, pp. 254-286. 